bioRxiv preprint doi: https://doi.org/10.1101/2020.12.10.420257; this version posted April 7, 2021. The copyright holder for this preprint (which

was not certified by peer review) is the author/funder, who has granted bioRxiv a license to display the preprint in perpetuity. It is made available under aCC-BY-NC-ND 4.0 International license.

Pan-pediatric cancer IncRNA study

Modi et al.

\title{
Integrative genomics identifies IncRNA regulatory networks across 1,044 pediatric leukemias and extra-cranial solid tumors
}

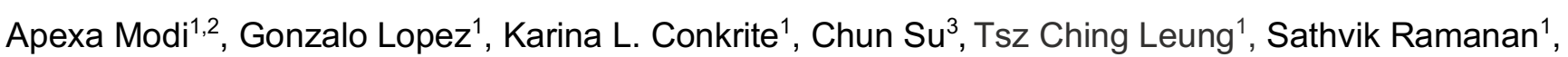
Elisabetta Manduchi ${ }^{3}$ Matthew E. Johnson ${ }^{3}$, Daphne Cheung ${ }^{1}$, Samantha Gadd ${ }^{4}$, Jinghui Zhang ${ }^{5}$, Malcolm A. Smith ${ }^{6}$, Jaime M. Guidry Auvil ${ }^{7}$, Daniela S. Gerhard ${ }^{6}$, Soheil Meshinchi ${ }^{8}$, Elizabeth J. Perlman ${ }^{4}$, Stephen P. Hunger ${ }^{1,9}$, John M. Maris ${ }^{1,9,11}$, Andrew D. Wells ${ }^{3,11}$, Struan F.A. Grant ${ }^{3,9,12,13}$, Sharon J. Diskin ${ }^{1,9,10^{*}}$

${ }^{1}$ Division of Oncology and Center for Childhood Cancer Research, Children's Hospital of Philadelphia, Philadelphia, Pennsylvania 19104, USA.

${ }^{2}$ Genomics and Computational Biology Graduate Group, Biomedical Graduate Studies, Perelman School of Medicine, University of Pennsylvania, Philadelphia, Pennsylvania 19104, USA.

${ }^{3}$ Center for Spatial and Functional Genomics, Children's Hospital of Philadelphia, Philadelphia, Pennsylvania, USA.

${ }^{4}$ Department of Pathology and Laboratory Medicine, Ann \& Robert H. Lurie Children's Hospital of Chicago, Robert H. Lurie Cancer Center, Northwestern University, Chicago, Illinois 60208, USA.

${ }^{5}$ Department of Computational Biology, St Jude Children's Research Hospital, Memphis, Tennessee 38105, USA

${ }^{6}$ Cancer Therapy Evaluation Program, National Cancer Institute, Bethesda, Maryland 20892, USA.

${ }^{7}$ Office of Cancer Genomics, National Cancer Institute, Bethesda, Maryland 20892, USA.

${ }^{8}$ Clinical Research Division, Fred Hutchinson Cancer Research Center, Seattle, Washington 98109, USA.

${ }^{9}$ Department of Pediatrics, Perelman School of Medicine at the University of Pennsylvania, Philadelphia, Pennsylvania 19104, USA.

${ }^{10}$ Abramson Family Cancer Research Institute, Perelman School of Medicine at the University of Pennsylvania, Philadelphia, Pennsylvania 19104, USA.

${ }^{11}$ Department of Pathology and Laboratory Medicine, Perelman School of Medicine at the University of Pennsylvania, Philadelphia, Pennsylvania 19104, USA.

${ }^{12}$ Department of Genetics, Perelman School of Medicine at the University of Pennsylvania, Philadelphia, Pennsylvania 19104, USA.

${ }^{13}$ Divisions of Human Genetics and Endocrinology \& Diabetes, Children's Hospital of Philadelphia, Philadelphia, Pennsylvania, 19104, USA.

\section{*Corresponding Author: diskin@email.chop.edu}


bioRxiv preprint doi: https://doi.org/10.1101/2020.12.10.420257; this version posted April 7, 2021. The copyright holder for this preprint (which was not certified by peer review) is the author/funder, who has granted bioRxiv a license to display the preprint in perpetuity. It is made

Pan-pediatric cancer IncRNA study

Modi et al. mechanistic studies.

\section{Abstract}

Long non-coding RNAs (IncRNAs) play an important role in gene regulation and contribute to tumorigenesis. While pan-cancer studies of IncRNA expression have been performed for adult malignancies, the IncRNA landscape across pediatric cancers remains largely uncharted. Here, we curate RNA sequencing data for 1,044 pediatric leukemia and solid tumors and integrate paired tumor whole genome sequencing and epigenetic data in relevant cell line models to explore IncRNA expression, regulation, and association with cancer. We report a total of 2,657 robustly expressed IncRNAs across six pediatric cancers, including 1,142 exhibiting histotype-specific expression. DNA copy number alterations contributed to IncRNA dysregulation at a proportion comparable to protein coding genes. Application of a multi-dimensional framework to identify and prioritize IncRNAs impacting gene networks revealed that IncRNAs dysregulated in pediatric cancer are associated with proliferation, metabolism, and DNA damage hallmarks. Analysis of upstream regulation via cell-type specific transcription factors further implicated distinct histotype-specific and developmental IncRNAs. We integrated our analyses to prioritize IncRNAs for experimental validation and showed that silencing of TBX2-AS1, our top-prioritized neuroblastoma-specific IncRNA, resulted in significant growth inhibition of neuroblastoma cells, confirming our computational predictions. Taken together, these data provide a comprehensive characterization of IncRNA regulation and function in pediatric cancers and pave the way for future 8 99 . 
bioRxiv preprint doi: https://doi.org/10.1101/2020.12.10.420257; this version posted April 7, 2021. The copyright holder for this preprint (which was not certified by peer review) is the author/funder, who has granted bioRxiv a license to display the preprint in perpetuity. It is made available under aCC-BY-NC-ND 4.0 International license.

Pan-pediatric cancer IncRNA study

Modi et al.

Long non-coding RNAs (IncRNAs) are transcribed RNA molecules greater than 200 nucleotides in length that do not code for proteins. These molecules account for $70 \%$ of the expressed human transcriptome and provide a key aspect of gene regulation ${ }^{1-4}$. Compared to protein coding genes (PCGs), IncRNAs typically have fewer exons, weaker conservation, and lower abundance ${ }^{3}$. Despite this, IncRNAs have been shown to play significant roles in both transcriptional and post-transcriptional gene regulation ${ }^{5}$. LncRNAs perform these roles by physically interacting with a variety of substrates, including proteins (transcription co-factors), RNAs (microRNA sponges), and DNA (chromatin interaction scaffolds) ${ }^{1,2,6,7}$. While the mechanisms and function for the majority of IncRNAs remain unknown ${ }^{3,8}$, those that have been experimentally characterized are involved in a variety of cellular processes ${ }^{6}$ including gene silencing $(A N R I L)^{9}$, modulation of chromatin architecture $(X i s t)^{10}$, and pre-mRNA processing $(M A L A T 1)^{11}$. LncRNAs are also important in development ${ }^{12}$. For example, the $H 19$ IncRNA is involved in imprinting ${ }^{13}$, while the well-conserved TUNA IncRNA controls stem cell pluripotency and lineage differentiation ${ }^{14}$. Dysregulation of IncRNA expression has been widely observed in cancer ${ }^{3,15,16}$ and studies have shown that IncRNAs play important roles in tumor initiation and progression ${ }^{17}$. LncRNAs can function as tumor suppressors, such as the PANDA IncRNA which regulates DNA damage response in diffuse large B-cell lymphoma ${ }^{18}$; however, many more IncRNAs appear to be oncogenes. Examples include the HOTAIR and PVT1 IncRNAs which promote proliferation in various cancers through tissue specific

91 mechanisms ${ }^{19,20}$. Pan-cancer analyses of IncRNA expression in adult malignancies have uncovered 92 many cancer-associated IncRNAs $3,15-17,21,22$. Identification of functional IncRNAs amongst the large set of 93 cancer-associated IncRNAs, however, remains challenging ${ }^{15,23}$. Current methods to identify putative 94 functional IncRNAs involve identifying IncRNA-specific genetic aberrations ${ }^{15,16,24}$ or using IncRNA 95 expression to predict overall patient survival ${ }^{16}$. To more systematically address how IncRNAs drive the 96 pathogenesis of cancer, recent computational methods seek to assign function to these molecules based 97 on predicted target genes and regulatory network models. These methods have been applied to adult 98 malignancies and allow for more focused hypotheses to be tested ${ }^{21,22}$. 
bioRxiv preprint doi: https://doi.org/10.1101/2020.12.10.420257; this version posted April 7, 2021. The copyright holder for this preprint (which was not certified by peer review) is the author/funder, who has granted bioRxiv a license to display the preprint in perpetuity. It is made available under aCC-BY-NC-ND 4.0 International license.

Pan-pediatric cancer IncRNA study

Modi et al.

LncRNA studies and evidence of related function in pediatric cancers have been primarily limited

100 to neuroblastoma $(\mathrm{NBL})^{25-30}$, T-lymphoblastic leukemia (T-ALL) $)^{31,32}$, and more recently glioblastoma ${ }^{33}$.

101 CASC15 and NBAT-1 are a sense-antisense IncRNA pair that map to a NBL susceptibility locus identified

102 by genome-wide association study ${ }^{26,34}$. Both IncRNAs are downregulated in high-risk NBL tumors and 103 have been shown to be involved in cell proliferation and differentiation ${ }^{25,26}$. In pediatric T-ALL, the 104 NOTCH-regulated IncRNA, LUNAR1, promotes T-ALL cell growth by sustaining IGF1 signaling ${ }^{32}$. To 105 date, it is unknown whether IncRNAs function as common drivers across multiple pediatric cancers, or if 106 instead, the majority of IncRNAs influence oncogenesis in a histotype-specific manner. Furthermore, 107 given that pediatric cancers typically arise from primitive embryonic and mesodermal cells, rather than 108 adult epithelial cells, it is unclear whether adult cancer IncRNA drivers will also be implicated in childhood 109 cancer.

Here, we perform a pan-pediatric cancer study of IncRNAs across 1,044 pediatric leukemias and

111 extra-cranial solid tumors ${ }^{35,36}$. We present the landscape of IncRNA expression across these childhood 112 cancers and perform integrative multi-omic analyses to assess tissue specificity, regulation, and putative 113 function. To validate our approach, we show that silencing of the top-prioritized NBL-specific 114 IncRNA, TBX2-AS1, impairs NBL cell growth in human-derived NBL cell line models.

117 The IncRNA landscape of pediatric cancers

118 To define the repertoire of IncRNAs expressed in childhood cancers, we analyzed RNA-sequencing data 119 from six distinct pediatric cancer histotypes profiled through the Therapeutically Applicable Research to 120 Generate Effective Treatments (TARGET) project (https://ocg.cancer.gov/programs/target/data-matrix) 121 (Online Methods; Supplementary Table 1). This curated set of 1,044 leukemia and solid tumor samples 122 includes 280 acute myeloid leukemia (AML), 190 B-lymphoblastic leukemias (B-ALL), 244 T123 lymphoblastic leukemias (T-ALL), 121 Wilms tumors (WT), 48 extracranial rhabdoid tumors (RT), and 124161 neuroblastomas (NBL) (Fig. 1a). Since one of our goals was to identify novel cancer-associated 
bioRxiv preprint doi: https://doi.org/10.1101/2020.12.10.420257; this version posted April 7, 2021. The copyright holder for this preprint (which was not certified by peer review) is the author/funder, who has granted bioRxiv a license to display the preprint in perpetuity. It is made available under ACC-BY-NC-ND 4.0 International license.

Pan-pediatric cancer IncRNA study

Modi et al.

125 IncRNAs, we performed guided de novo transcriptome assembly using StringTie v1.3.3 ${ }^{37}$ with the 126 GENCODE v19 database ${ }^{38}$ as a gene annotation reference (Supplementary Fig. 1). Expressed gene 127 sequences that did not match exons and transcript structures of any known gene in the GENCODE v19 128 or RefSeq v74 databases were considered putative novel genes (Supplementary Fig. 1, Online 129 Methods). Of these novel genes, we identified candidate IncRNAs by using the PLEK v1 algorithm ${ }^{39}$ to 130 assess non-coding potential, and then additionally filtered hits by transcript length, exon read coverage, 131 and genomic location (Fig. 1a, Online Methods, Supplementary Fig. 1). As validation of our IncRNA 132 discovery pipeline, we observed that 36\% (87 of 242) of identified novel IncRNAs not annotated in 133 Gencode v19 (hg19) were indeed annotated in the more recent Gencode v29 (hg38) genome build 134 (Supplementary Table 2). To ensure that we selected robustly expressed genes in the setting of cancer heterogeneity and sequencing variability, we applied a conservative expression cutoff of Fragments Per Kilobase of transcript per Million mapped reads (FPKM) $>1$ in at least $20 \%$ of samples for each cancer.

137 Across all cancers there were 15,588 PCGs, 2,512 known IncRNAs, and 145 novel IncRNAs expressed, 138 though the total number of expressed genes varied per cancer (Fig 1b, Supplementary Table 3). 139 Principal component analysis (PCA) of IncRNA gene expression showed that blood (AML, B-ALL, T-ALL) 140 and solid (NBL, WT, RT) cancers form two distinct groups. Moreover, individual cancer histotypes 141 clustered more closely using IncRNA expression than PCG expression alone (Supplementary Fig. 2a142 b), consistent with the known tissue specific nature of IncRNA expression and function ${ }^{3}$.

143 Overall, IncRNAs had lower average expression compared to PCGs resulting in fewer highly 144 expressed IncRNAs (Supplementary Fig. 2c). Between 10-100 (3.7\%) IncRNAs accounted for 50\% of 145 the total sum of IncRNA expression (Fig. 1c). In contrast, between 100-1000 (6.4\%) PCGs accounted for $14650 \%$ of the total sum of PCG expression (Fig. 1d). We examined the union of the top five most highly 147 expressed IncRNAs across pediatric cancers (total 11 IncRNAs). Some of these IncRNAs had higher 148 expression in the blood cancers (MALAT1 and RP11-386/14.4), in the solid cancers (H19), or in only one 149 cancer, such as MEG3 and RP11-386G11.10 in NBL (Fig. 1e). Five of these IncRNAs were among the 150 top 10 IncRNAs expressed across normal tissues in the Genotype-Tissue Expression (GTEx) project ${ }^{40}$. 
bioRxiv preprint doi: https://doi.org/10.1101/2020.12.10.420257; this version posted April 7, 2021. The copyright holder for this preprint (which was not certified by peer review) is the author/funder, who has granted bioRxiv a license to display the preprint in perpetuity. It is made available under aCC-BY-NC-ND 4.0 International license.

Pan-pediatric cancer IncRNA study

Modi et al.

Specifically, C17orf76-AS1 (LRRC75A-AS1), MALAT1, GAS5, SNHG6, SNHG8 were expressed 152 ubiquitously in 30 of the 49 GTEx tissues (Supplementary Table 4).

\section{Tissue specific IncRNA expression distinguishes pediatric cancers}

155 To evaluate more formally the tissue specific expression of IncRNAs, we annotated all genes with a tissue 156 specificity index (tau score) $)^{41,42}$ (Online Methods). The established tau score ranges from 0 (ubiquitous 157 expression) to 1 (tissue-specific). As an example, the highly expressed IncRNA C17orf76-AS1 yielded a 158 tau score of 0.296 in this study, indicating ubiquitous expression (Supplementary Fig. 2d). In contrast, 159 the highly expressed MEG3 IncRNA, which is known to have tissue-specific expression in $\mathrm{NBL}^{30,43}$, 160 yielded a tau score of 0.986 (Supplementary Fig. 2e). Overall, we observed that IncRNAs yielded a 161 higher tau score range and mean, and thus greater tissue specific expression than PCGs (t-test $162 p=1.62 \times 10^{-42}$ ). Novel IncRNAs had the greatest tissue specific expression (t-test: vs proteins- $p=1.62 \times 10^{-}$ $163{ }^{42}$, vs known IncRNAs- $p=3.39 \times 10^{-13}$ ) (Fig. 2a). A tau score threshold of 0.8 has been suggested to 164 distinguish tissue specific genes ${ }^{42}$, and using this cutoff we identified $1,142(42 \%)$ tissue specific (TS) IncRNAs (Fig. 2b, Supplementary Table 5). To assess how well TS IncRNAs distinguish cancers, we performed clustering based on the top five highest expressed TS IncRNAs per cancer (30 total). The expression of just these IncRNAs was sufficient to cluster samples of the same cancer type (Fig. 2c).

168 Furthermore, the blood and solid cancers separately clustered together with little expression overlap 169 observed between the two groups across the 30 genes (Fig. 2c). Finally, we identified a similar proportion 170 of TS IncRNAs $(38 \%, \mathrm{n}=1624)$ across 12 adult cancers from The Cancer Genome Atlas (TCGA) (Online 171 Methods) and observed that adult cancer tissue types were also well distinguished based on the 172 expression of the top 5 most TS IncRNAs (Supplementary Fig. 2f-g).

173 Notably, NBL tumors expressed $2.5 x$ more TS IncRNAs $(n=522)$ than the cancer with the next 174 highest: WT (TS IncRNAs: n=211), and 10x more than AML, which had the least number of TS IncRNAs 175 (n=49) (Fig. 2b). To validate NBL's striking quantity of TS IncRNAs, we first assessed whether immune 176 and stromal cell infiltration ${ }^{36}$ could be contributing to the variety of IncRNAs expressed. We ran the 
bioRxiv preprint doi: https://doi.org/10.1101/2020.12.10.420257; this version posted April 7, 2021. The copyright holder for this preprint (which was not certified by peer review) is the author/funder, who has granted bioRxiv a license to display the preprint in perpetuity. It is made available under aCC-BY-NC-ND 4.0 International license.

Pan-pediatric cancer IncRNA study

Modi et al.

177 ESTIMATE algorithm as previously described ${ }^{36}$ (Online Methods) to determine levels of immune and 178 stromal cell presence in each tumor sample using expression data. Using these purity estimates, we re179 calculated each cancer's tau score and restricted our analysis to NBL samples with either $80 \%$ or $90 \%$ 180 purity. In both cases, we found that NBL still had the greatest number of TS IncRNAs ( $n=588-N B L 90 \%$ 181 purity) compared to other cancers (Supplementary Table 6). Finally, given that the TARGET NBL RNA182 seq dataset is un-stranded, we validated our findings using stranded RNA-seq data in an independent 183 NBL cohort generated through the Gabriela Miller Kids First (GMKF) program $(n=223)$. We observed that $18448 \%$ of expressed IncRNAs were tissue specific in the GMKF cohort, an increase from the $31 \%$ observed 185 in the TARGET cohort (Supplementary Table 6). These results confirm IncRNA abundance in NBL and demonstrate that the tau score robustly identifies TS IncRNAs across varying datasets.

\section{Somatic DNA copy number alterations impact IncRNA expression}

Many pediatric cancers are marked by a lower single nucleotide variant (SNV) and insertion-deletion (indel) burden than observed in adult cancers ${ }^{36}$. Instead, large chromosomal events, such as somatic copy number aberrations (SCNAs) and other structural variants (SVs) have been shown to dysregulate protein coding driver genes ${ }^{36,44}$. However, the extent to which large chromosomal alterations impact IncRNAs in pediatric cancers remains unknown. We thus sought to identify SCNAs and SVs using

194 whole genome sequencing (WGS) data from the TARGET project available for NBL ( $n=146), B-A L L$ 195 ( $n=302)$, AML $(n=297)$, and WT (n=81) (Online Methods). We observed that NBL had the greatest 196 frequency of copy number events (Supplementary Fig. 3a). The GISTIC v2 algorithm ${ }^{45}$ was applied 197 to detect regions of recurrent SCNA (q-value < 0.25). We identified 673 expressed IncRNAs 198 overlapping 176 significant SCNA regions across the cancers (Supplementary Table 7). WGS 199 samples with matched RNA-sequencing were then used to compare IncRNA expression in samples 200 with or without an SCNA event and determine significant differential expression (DE) (Online 201 Methods, Supplementary Table 8). Across all cancers, between $10-30 \%$ of expressed genes 202 overlapping SCNA regions showed significant differential expression based on SCNA, a proportion 
bioRxiv preprint doi: https://doi.org/10.1101/2020.12.10.420257; this version posted April 7, 2021. The copyright holder for this preprint (which was not certified by peer review) is the author/funder, who has granted bioRxiv a license to display the preprint in perpetuity. It is made available under aCC-BY-NC-ND 4.0 International license.

Pan-pediatric cancer IncRNA study

Modi et al.

203 that was similar for both PCGs and IncRNAs (Fig 3a). Altogether, there were 198 (29\%) unique 204 IncRNAs with significant DE due to SCNA (Supplementary Fig 3b). The majority of the significantly 205 dysregulated IncRNAs were identified in the two cancers with the greatest overall number of 206 expressed IncRNAs, NBL and WT, and mapped to regions with highly recurrent SCNAs in those 207 cancers (chromosomes 1, 7, 11, and 17) (Fig 3b).

208 While SCNAs can cause the dysregulation of IncRNA expression based on gene dosage, 209 structural variant (SV) breakpoints within a IncRNA could cause loss or gain of function ${ }^{36,44}$. We utilized 210 WGS data to identify IncRNAs disrupted by SV breakpoints using a previously described combination 211 approach involving copy number read-depth and discordant junction approach ${ }^{44}$ (Online Methods).

212 There were 650 unique expressed IncRNA genes disrupted by SVs, $89 \%$ of which were found in only 213 one sample (Supplementary Fig. 4a). We observed 212 SV-impacted IncRNA genes located at 214 SCNA regions (Fig. 3c), and 65\% of IncRNAs genes disrupted by SV breakpoints in at least five 215 samples were located at SCNA regions (Supplementary Fig. 4b, Supplementary Table 9). Indeed, 216 the top-ranked SV-impacted IncRNA in both NBL and WT, MYCNOS, associates with the disease217 driving chr2p24 amplification ${ }^{46,47}$ (Supplementary Fig. 4c-d). In B-ALL, the SV-impacted IncRNAs: 218 KIAA0125 and CDKN2B-AS1 (ANRIL) associate with the well-studied IGH translocation and $219 C D K N 2 A / B$ deletion locus (Supplementary Fig. 4e) $)^{48}$. The top-ranked SV-impacted IncRNA in AML, 220 MIR181A1HG (MONC), associates with a recurrent SCNA deletion on 1q and is mildly up-regulated 221 in the AML dataset ( $p=0.061$, Supplementary Fig. 4f). MIR181A1HG (MONC) was described 222 previously as an oncogene in acute megakaryoblastic leukemia ${ }^{49,50}$. Finally, we observed 30 IncRNAs 223 with pan-cancer ( $\mathrm{n}>3$ ) expression and SV breakpoints(Supplementary Fig. 4h). The most number of 224 breakpoints across unique samples was observed in LINC00910, which was shown previously to be 225 essential for cell growth in the K562 cell line ${ }^{51}$. 
bioRxiv preprint doi: https://doi.org/10.1101/2020.12.10.420257; this version posted April 7, 2021. The copyright holder for this preprint (which was not certified by peer review) is the author/funder, who has granted bioRxiv a license to display the preprint in perpetuity. It is made available under aCC-BY-NC-ND 4.0 International license.

Pan-pediatric cancer IncRNA study

Modi et al.

To determine how IncRNAs may drive pediatric cancers, we examined the downstream impact of IncRNAs on gene regulation. We focused on identifying IncRNAs that mediate transcriptional regulation by modulating TF activity (IncRNA modulators) ${ }^{52-55}$. We wrote custom scripts implementing the IncMod computational framework $^{56}$ (Online Methods) to first identify DE-IncRNAs and then to assess their impact on correlated expression between a TF and its target genes ${ }^{21,56}$ (Fig. 4a, Online Methods). Across all cancers studied, we identified 313,370 unique, dysregulated IncMod triplets (IncRNA-TF-target gene), representing $0.02-0.2 \%$ of possible triplets, which have significant correlation differences between a TF and target gene upon IncRNA expression dysregulation (Supplementary Table 10-11). This proportion was consistent with previous findings from the IncMap study in adult cancers ${ }^{21}$, although more triplets were identified in datasets with greater sample size (Supplementary Table 10-11). LncRNA modulators were categorized into one of three categories based on their impact on TF-target gene correlation; either the correlation was enhanced, attenuated, or inverted (Fig 4a-b). IncRNA modulators have context specific function such that for different TF-target gene pairs they could exert different types of regulation (Supplementary Fig. 5b). The majority of IncRNA modulators appeared to be active in only one cancer, with only 15\% (138 of 923 IncRNAs) having pan-cancer activity (n>3) (Fig. 4c).

To determine the biological impact of IncRNA modulators, we identified IncRNAs whose target genes were enriched in MSigDB's Hallmark Gene Sets $(H M S)^{57}$ (Fisher's exact test, FDR < 0.1; Online Methods). Across the majority of cancers, IncRNA modulator target genes had significant enrichment in the proliferation, metabolism, and DNA damage hallmark categories (FDR range: 0.1 to $2.24 \times 10^{-36}$; Fig. 4d). Overall, the top-enriched hallmark pathways closely mirrored those found for IncRNA modulators in adult cancers $^{22}$. Consistent with its role in development and as an oncogene in certain cancers ${ }^{23}$, the top-enriched hallmarks for the H19 IncRNA, dysregulated in NBL, were the EMT (development) and G2Mcheckpoint (proliferation) hallmarks (Supplementary Fig. 5c). The blood cancers exhibited strong enrichment of IncRNA modulators regulating MYC targets, which has a well-established role in leukemias $^{58}$. Furthermore, in AML, we observed that gene targets of the myeloid-specific IncRNA, 
bioRxiv preprint doi: https://doi.org/10.1101/2020.12.10.420257; this version posted April 7, 2021. The copyright holder for this preprint (which was not certified by peer review) is the author/funder, who has granted bioRxiv a license to display the preprint in perpetuity. It is made available under aCC-BY-NC-ND 4.0 International license.

Pan-pediatric cancer IncRNA study

Modi et al.

HOTAIRM1, were most enriched for proliferation hallmarks (Supplementary Fig. 5d), consistent with this IncRNA's known role in proliferation as an oncogene in adult $\mathrm{AML}^{59}$.

Finally, we sought to determine potential IncRNA mechanism by identifying recurring patterns of regulation amongst IncMod triplets. To this end, we nominated candidate IncRNA-TF associations by ranking TF's based on the number of target genes regulated by each given TF (Supplementary Table 12). As proof-of-concept, we were able to detect known IncRNA-TF associations such as GAS5 with E2F4 ${ }^{60}$ (RNA-protein), and SNHG1 with TP53 ${ }^{61}$ (RNA-RNA) amongst IncMod triplets in our study (Supplementary Fig. 5e-f). A notable example from the hundreds of novel associations identified is between the B-ALL specific IncRNA, BLACE (B-cell acute lymphoblastic leukemia expressed, tau score: 0.999) and its top associated TF, XBP1, which has known roles in pre-B-ALL cell proliferation and tumorigenesis $^{62}$ (Fig 4e-f). These predictions of IncRNA transcriptional networks provide focused avenues to elucidate the mechanisms through which IncRNAs can drive pediatric cancers.

\section{Defining the role of IncRNAs in childhood cancer development}

Pediatric cancers arise in the context of normal human development where cells do not differentiate as they should, resulting in malignant cell transformation ${ }^{63}$. Some tumors are comprised of heterogenous cells that resemble varying differentiation lineages with distinct transcriptomic states due to distinct super enhancer transcription factor networks ${ }^{64,65}$. We sought to uncover IncRNAs associated with these varying cell lineages as they may contribute to pediatric cancer etiology. We used NBL as a model given its heterogeneity and two confirmed tumor cell states: the undifferentiated mesenchymal (MES) cells and the committed adrenergic (ADRN) cells, which can interconvert ${ }^{66}$. Given that NBL precursor cells, the neural crest cells, have been shown to have a more MES gene expression signature ${ }^{65,66}$, we hypothesized that IncRNAs correlated with an MES signature may play a role in NBL development. Using the gene set variation analysis (GSVA) method $^{67}$ we assigned for each NBL Stage 4 sample, both a MES and ADRN score (Online Methods). Using hierarchical clustering (Supplementary Figure 6a) we 
bioRxiv preprint doi: https://doi.org/10.1101/2020.12.10.420257; this version posted April 7, 2021. The copyright holder for this preprint (which was not certified by peer review) is the author/funder, who has granted bioRxiv a license to display the preprint in perpetuity. It is made available under aCC-BY-NC-ND 4.0 International license.

Pan-pediatric cancer IncRNA study

Modi et al.

categorized samples based on their primary gene expression phenotype as ADRN, MES, or mixed (Fig 5a). We next correlated the MES and ADRN score with IncRNA expression across NBL samples. We observed 29 IncRNAs associated with MES samples and 21 IncRNAs associated with ADRN samples (Fig 5b) (Spearman's |rho| $>0.6$, adj. pval < 0.01). We then performed a guilt-by-association analysis ${ }^{68}$ to determine the potential functional pathway for these IncRNAs based on the pathway of their correlated protein coding genes (Online Methods). Gene set enrichment was performed using the gene ontology (GO) biological processes gene set. Intriguingly, the ADRN group of IncRNAs showed enrichment for DNA replication and cell cycle associated gene sets, whereas the MES IncRNAs were associated with organ development and immune response (Fig $\mathbf{5 b}$ ). We validated these same pathway results in an independent analysis of the GMKF NBL cohort restricted to Stage 4 samples $(n=67)$ (Supplementary Figure 6b). Across both TARGET and GMKF cohorts we observed 13 IncRNAs strongly associated with MES samples (Supplementary Table 6c), which warrant further study for their potential role in NBL development.

\section{Identification of potential cancer driver IncRNAs via integration of epigenetic data}

To better identify ADRN IncRNAs we elucidated IncRNAs directly regulated by the known ADRN transcription factors (TFs): MYCN, PHOX2B, HAND2, GATA3, ISL1, and TBX2 ${ }^{65,69}$. This set of TFs, which are co-bound and auto-regulated, are known as the core transcriptional circuitries (CRC) and drive the ADRN cell lineage in $\mathrm{NBL}^{65,69}$. CRC gene regulation occurs both by direct promoter binding (Fig. 5c-1) and by distal binding to either promoters (Fig. 5c-2) or enhancer regions (Fig. 5c-3) which then regulate the gene of interest via long-range chromatin interactions ${ }^{65,69-71}$. CRC-bound regulatory loci were identified from publicly available ChIP-seq data for all ADRN TFs across two MYCN-amplified NBL cell lines: SKNBE(2)C and KELLY ${ }^{69,72}$ (Online Methods). To comprehensively identify both short- and longrange $\mathrm{CRC}$ gene regulation, we generated high-resolution (i.e. using 4-cutter restriction enzyme DpnII) genome-wide promoter-focused Capture $C^{73}$ in the NBL cell line NB1643. After pinpointing gene 
bioRxiv preprint doi: https://doi.org/10.1101/2020.12.10.420257; this version posted April 7, 2021. The copyright holder for this preprint (which was not certified by peer review) is the author/funder, who has granted bioRxiv a license to display the preprint in perpetuity. It is made available under aCC-BY-NC-ND 4.0 International license.

Pan-pediatric cancer IncRNA study

Modi et al.

303 promoters interacting with CRC TF bound regulatory loci (promoters or enhancers) (Fig. 5c, Online 304 Methods), we identified 547 IncRNA genes associated with the NBL CRC (Fig 5d, Supplementary 305 Table 13), with only 249 of these IncRNA genes being bound by CRC TFs within their promoter regions. 306 We further distinguished 313 ADRN IncRNAs based on differential expression (DE) between ADRN and 307 MES samples (Fig 5d, Supplementary Table 14). The TBX2-AS1 DE-IncRNA was highly correlated to 308 the CRC TF: TBX2 (Pearson's $r=0.77$ ), and both are up-regulated in ADRN samples (Fig 5e). CRC 309 binding is observed at both the shared promoter region of TBX2 and TBX2-AS1 and at an interacting 310 distal enhancer (Fig 5f). TBX2 was recently shown to be involved in NBL cell proliferation, ${ }^{74}$ but the role 311 of TBX2-AS1 in NBL is unknown.

To further demonstrate the utility of this epigenetic based prioritization, we applied the same 313 method to T-ALL, which also has a well-established set of CRC TFs (TAL1, MYB, GATA3, and RUNX1) ${ }^{71}$. 314 We used available ChIP-seq and ChIA-PET data for the TAL1 mutated T-ALL cell lines, Jurkat and 315 CCRF-CEM, to identify loci bound by the T-ALL CRC TF's ${ }^{71}$ (Online Methods). We not only identified 316 the known leukemia associated IncRNA PVT1, but also 9 other T-ALL CRC IncRNAs prioritized based 317 on correlation with T-ALL PCGs and differential expression associated with a previously defined TAL1318 subgroup $^{75}$ (Supplementary Figure 7, Supplementary Table 13-15). Taken together, this novel data 319 integration method nominates multiple IncRNAs with previously unknown function for further study as 320 potential driver genes in pediatric cancer.

Integrative multi-omic analysis prioritizes TBX2-AS1 as a candidate functional IncRNA in NBL

323 To obtain a comprehensive prioritization of candidate functional IncRNAs for each cancer histotype, 324 we integrated information for (1) tissue specific expression, (2) dysregulation due to DNA copy number 325 aberration, and (3) regulation by CRC TFs (Supplementary Table 16). Here, we focus on the NBL 326 cohort since this cancer has data available for all of the prioritization steps (Supplementary Table 327 17). The top ranked IncRNA in NBL was MEG3, which has a known role in both NBL and other 
bioRxiv preprint doi: https://doi.org/10.1101/2020.12.10.420257; this version posted April 7, 2021. The copyright holder for this preprint (which was not certified by peer review) is the author/funder, who has granted bioRxiv a license to display the preprint in perpetuity. It is made available under aCC-BY-NC-ND 4.0 International license.

Pan-pediatric cancer IncRNA study

Modi et al.

328 cancers $^{43}$. The next notable IncRNA, TBX2-AS1, is up-regulated due to chromosome 17q gain (Fig 329 6a), has NBL-specific expression (tau score: TBX2- 0.807, TBX2-AS1- 0.86; Supplementary Fig. 8a), 330 and is co-regulated with TBX2. TBX2 has been shown to drive NBL proliferation via the FOXM1/E2F1

331 gene regulatory network ${ }^{72}$ and we hypothesized that TBX2-AS1 may play a similar role because 332 predictions from our IncMod analysis indicated that TBX2-AS1 impacts E2F targets and G2M 333 checkpoint genes (Fig. 6b). Furthermore, the TFs primarily impacted by TBX2 knockdown ${ }^{72}$, MYBL2 $^{2}$ 334 and E2F1, were found to have the most target genes predicted to be regulated by TBX2-AS1 (Fig 6c335 d). Evidence for this association was further supported by the correlation (Spearman's rho > 0.4) 336 between TBX2-AS1 and TBX2's target TFs, including: FOXM1, E2F1, and MYBL2 (Supplementary 337 Fig. 8b). While the strong correlation between TBX2-AS1 and TBX2 may confound our predictions, a 338 previous study showed positionally conserved IncRNAs ${ }^{59}$, such as TBX2-AS1, often regulate their neighboring developmental TFs (TBX2) and can play roles in genome organization and cancer ${ }^{59}$. Based on the promising in silico evidence, we prioritized TBX2-AS1 for experimental study.

\section{Silencing of TBX2-AS1 inhibits cell growth of neuroblastoma cells}

344 TBX2-AS1 expression across 38 NBL cell lines using RNA-seq ${ }^{76}$ (Supplementary Fig 8c). Expression 345 of TBX2 and TBX2-AS1 were subsequently validated in eight cell lines using RT-qPCR 346 (Supplementary Fig. 8d). We selected NLF and SKNSH models for further study based on their high 347 TBX2-AS1 expression and differing expression levels of TBX2. Silencing of TBX2-AS1 using small 348 interfering RNA (siRNA) achieved $92 \%$ and $63 \%$ reduction of TBX2-AS1 expression in NLF and 349 SKNSH, respectively (Fig. 6e). We also observed down-regulation of TBX2 protein levels in the 350 siTBX2-AS1 treated cells for both cell lines (Fig. 6f). Given the known role of TBX2 in NBL cell 351 proliferation ${ }^{74}$, we measured cell growth of siTBX2-AS1 treated NBL cells to determine if TBX2-AS1 352 has similar function. When the non-targeting control (siNTC) treated cells reached confluence, the 353 siTBX2-AS1 treated cell index was reduced by $42.6 \%$ and $36.8 \%(n=3, p<0.01)$ in the NLF and 
bioRxiv preprint doi: https://doi.org/10.1101/2020.12.10.420257; this version posted April 7, 2021. The copyright holder for this preprint (which

was not certified by peer review) is the author/funder, who has granted bioRxiv a license to display the preprint in perpetuity. It is made available under ACC-BY-NC-ND 4.0 International license.

Pan-pediatric cancer IncRNA study

Modi et al.

354 SKNSH cell line, respectively (Fig. 6g-h, Supplementary Fig. 8e). Live cell imaging using the 355 IncuCyte revealed changes in cell morphology for siTBX2-AS1 treated NLF cells, featuring an 356 appearance of disrupted cell to cell adhesion and elongated cell body (Supplementary Fig. 8f). To 357 identify pathways impacted by TBX2-AS1 knockdown, we performed total RNA sequencing in triplicate 358 of NLF cells and compared gene expression in control (siNTC) vs siTBX2-AS1 treated cells 359 (Supplementary Fig. 8g). Gene set enrichment analysis (GSEA) of the 364 significantly up-regulated 360 genes (log-fold change $>1.5$, adj pval $<0.1)$ revealed enrichment (FDR $<0.1)$ for hallmarks associated 361 with inflammation including: TNFA signaling and interferon gamma response (Supplementary Table 362 18). Across the 544 down-regulated genes, E2F target genes hallmark was most enriched. To 363 determine whether differentially expressed genes shared common regulation, we used the iRegulon 364 program $^{77}$, to search for TF motifs and ENCODE ChIP-seq tracks upstream of genes (Online 365 Methods). Using a normalized enrichment score (NES) of at least 3, we observed motif enrichment 366 for the neuronal differentiation repressor REST and the RFX family of transcription factors in $59 \%$ of 367 siTBX2-AS1 up-regulated genes (Fig. 6i). In 42\% of downregulated genes, the top enriched TFs were 368 MYBL2 and E2F1, corroborating our GSEA results. Moreover, both the growth assays and gene 369 expression profiling confirmed our IncMod results, which showed that TBX2-AS1 impacts NBL 370 proliferation by modulating target genes of E2F1 and MYBL2 (Fig. 6b-d). These data thus demonstrate 371 the utility of our integrative IncRNA characterization and prioritization approach for future validation 372 experiments across all cancers considered in this study. Furthermore, we uncovered a functional role for 373 TBX2-AS1 in NBL proliferation likely mediated via the regulation of TBX2 and its known target genes: 374 E2F, MYBL2, and REST ${ }^{72}$.

\section{Discussion}

377 LncRNAs have emerged as important regulators of gene expression and their dysregulation can impact 378 key cancer pathways and drive tumorigenesis ${ }^{1-4}$. Despite this, relatively few IncRNAs have been 
bioRxiv preprint doi: https://doi.org/10.1101/2020.12.10.420257; this version posted April 7, 2021. The copyright holder for this preprint (which was not certified by peer review) is the author/funder, who has granted bioRxiv a license to display the preprint in perpetuity. It is made available under aCC-BY-NC-ND 4.0 International license.

Pan-pediatric cancer IncRNA study

Modi et al.

experimentally characterized and the landscape of IncRNA expression across pediatric cancers has been previously unknown. In this study, we explored IncRNA expression, cancer association, and regulatory networks across 1,044 pediatric leukemias and solid tumors, representing six different cancer types. The

382 breadth of samples and cancer types included allowed for robust identification of novel, cancer-specific, 383 and developmental IncRNAs. Furthermore, we used systems modelling to identify expression patterns

384 for both up- and downstream IncRNA gene regulation. Altogether we provide multi-dimensional insight 385 into the predicted biological and functional relevance of IncRNAs by integrating WGS, ChIP-seq, 386 chromatin capture, and predictions of transcriptional networks. specific nature of IncRNAs. We report a total of 2,657 robustly expressed IncRNAs across the six cancer types studied. This number is notably smaller than reports from pan-cancer studies of adult malignancies ${ }^{15,17}$, likely due to the smaller number of cancer types studied here and conservative expression threshold applied. However, similar to our findings in adult cancers, $43 \%(1,142 / 2,657)$ of expressed IncRNAs exhibited tissue-specific (TS) expression across pediatric cancers. Indeed, IncRNAs had significantly greater tissue specificity than protein coding genes, making them more ideal candidates as biomarkers. Currently there is one IncRNA, PCA3, that is FDA-approved as a biomarker for prostate cancer $^{78}$ and multiple trials investigating ncRNAs in cancer prognostics are underway ${ }^{79}$. In this study, the top five most TS IncRNAs per cancer were sufficient to differentiate each cancer histotype. Furthermore, we identify IncRNAs specific to distinct cell lineages within NBL, suggesting there is potential for IncRNAs to be used as highly sensitive markers to differentiate cancer subtypes more accurately.

Typically, investigation of IncRNA dysregulation involves comparing IncRNA expression between

402 cancer and normal control samples and is an analysis that amply yields adult-cancer associated 403 IncRNAs ${ }^{15}$. However, the lack of normal expression controls for the majority of pediatric cancers ${ }^{36}$ is a 404 major complication in defining pediatric cancer-associated IncRNAs. To overcome this, we leveraged 
bioRxiv preprint doi: https://doi.org/10.1101/2020.12.10.420257; this version posted April 7, 2021. The copyright holder for this preprint (which was not certified by peer review) is the author/funder, who has granted bioRxiv a license to display the preprint in perpetuity. It is made available under aCC-BY-NC-ND 4.0 International license.

Pan-pediatric cancer IncRNA study

Modi et al.

405 information about how pediatric cancers are epigenetically regulated. In particular, NBL, is composed of 406 two cells lineages representing different development stages and each with distinct super-enhancer 407 transcription factor networks. Given the tie between organogenesis and tumorigenesis in pediatric 408 cancer $^{63}$, we hypothesized that IncRNAs associated with these cell states may also be involved in NBL 409 development. After correlation and pathway analysis, we discovered that IncRNAs associated with the 410 mesenchymal cell lineage had enrichment for organogenesis gene sets, while adrenergic-associated 411 IncRNAs were predicted to be involved in proliferation based on enrichment for DNA replication and cell 412 cycle gene sets. The majority of NBL samples have cells with an adrenergic gene expression signature, 413 which could suggest that ADRN IncRNAs are major drivers of disease and thus potential therapeutic 414 targets. To better identify these ADRN IncRNAs, we integrated ChIP-sequencing of core regulatory 415 (CRC) transcription factors for ADRN cells with our expression data to identify cancer driver IncRNAs. CRC TFs bind to cell-type-specific enhancers and regulate the expression of cell-type-specific genes ${ }^{80}$.

417 By taking advantage of this information we were able to prioritize IncRNAs likely to be important for cancer 418 cell identity based on CRC TF regulation. CRC TFs have been well defined for NBL and T-ALL ${ }^{69,71}$; 419 however the fact that they largely bind enhancer regions necessitated that we also use chromatin 420 interaction data to accurately determine regulated genes. Incorporation of these datasets allowed us to 421 identify 2-fold more CRC regulated IncRNAs in NBL and 3-fold in T-ALL as compared to using just ChIP422 seq data alone, which restricts IncRNA identification to those with CRC TFs bound at their promoter. 423 Notably, there were ten common CRC-regulated IncRNAs between NBL and T-ALL, and an important 424 next step for further identification of pan-pediatric cancer associated IncRNAs is application of this novel 425 analysis to a broader set of pediatric cancers.

While upstream regulation can help nominate cancer-associated IncRNAs, determining the 428 mechanism through which dysregulated IncRNAs impact downstream target genes is also crucial. 429 However, prediction of IncRNA function is limited given that very few IncRNA mechanisms have been 430 fully established and IncRNAs lack conserved sequence and structure ${ }^{81}$. Many studies instead use 
bioRxiv preprint doi: https://doi.org/10.1101/2020.12.10.420257; this version posted April 7, 2021. The copyright holder for this preprint (which

was not certified by peer review) is the author/funder, who has granted bioRxiv a license to display the preprint in perpetuity. It is made available under aCC-BY-NC-ND 4.0 International license.

Pan-pediatric cancer IncRNA study

Modi et al.

431 correlated protein coding gene expression as a proxy to define IncRNA pathways, but this approach often

432 results in many false positives and does not provide mechanistic insight ${ }^{81}$. To address this, we used the 433 IncMod method ${ }^{21,56}$ to model the functional mechanism of dysregulated IncRNAs by examining correlated 434 changes in transcription factor to target gene regulation. We used motif presence and regression analysis 435 to identify TF-target gene relationships, though future studies will be strengthened by incorporating TF 436 ChIP-seq data, when it becomes more widely available for pediatric cancers. Nevertheless, we were able 437 to successfully associate IncRNAs to TFs with known interactions, such as SNHG1 with TP53, while also 438 providing a prioritized list of novel associations that serve as a starting point for future experimental 439 studies such as RIP/MS ${ }^{82}$ and ChiRP-seq ${ }^{83}$. Finally, while our IncMod analysis was focused on 440 transcriptional regulation, the addition of microRNA binding and RNA-binding protein data, as utilized in 441 adult cancers ${ }^{22}$, is an important next step in understanding how IncRNAs impact post-transcriptional regulation in pediatric cancers.

Our study delineated high confidence IncRNA expression across pediatric cancers within the restrictions set by the sequencing depth and RNA-seq type available per cancer dataset. We required RNA-seq samples included in our study to have at least 10 million reads and read length of at least 75 447 bp; and with the exception of the T-ALL samples, all samples were poly-A selected. Future studies 448 involving total RNA-seq, greater sequencing depth, and longer read sizes could capture a larger diversity 449 and more accurate set of expressed IncRNAs by accounting for non-polyadenylated genes and 450 identifying scarcer or temporally expressed IncRNAs. Nevertheless, our high confidence set of IncRNAs 451 are very likely to be functional given that low or rare expression can be an indicator of transcriptional 452 noise ${ }^{84}$. In addition to having a limited number of RNA matched WGS samples, the Complete Genomics 453 short read technology limits the detection of structural variants based on size as previously described ${ }^{36,44}$.

454 The use of long-read sequencing and greater sequencing depth in future studies will enable more 455 accurate copy number and structure variant detection in pediatric cancers. 
bioRxiv preprint doi: https://doi.org/10.1101/2020.12.10.420257; this version posted April 7, 2021. The copyright holder for this preprint (which was not certified by peer review) is the author/funder, who has granted bioRxiv a license to display the preprint in perpetuity. It is made

Pan-pediatric cancer IncRNA study

Modi et al.

Finally, multi-dimensional integration of our computational predictions resulted in the nomination

458 of functionally relevant IncRNAs in each pediatric cancer. We annotated tissue specificity, copy number, 459 pathway, and likely targets for these IncRNAs, providing a solid foundation for mechanistic studies. As 460 proof-of-principle, we demonstrate that the top-prioritized tissue-specific and copy number dysregulated 461 IncRNA, TBX2-AS1, impacts NBL cell growth, validating our approach, while transcriptomic profiling 462 corroborated our pathway predictions. Knockdown of TBX2-AS1, showed downregulation of genes 463 regulated by E2F1 and MYBL2, the same TFs impacted upon TBX2 knockdown ${ }^{72}$. Future studies could 464 reveal whether TBX2-AS1 modulates TBX2 through direct binding or by impacting transcriptional 465 regulation at their shared locus. TBX2-AS1 was previously shown to be among a group of IncRNAs which 466 are positionally conserved and near developmental associated TFs ${ }^{59}$. This group of IncRNAs and their 467 neighboring TFs, typically have tissue specific expression, can be involved in cancer development, and 468 affect each other's expression ${ }^{59}$, all of which we observed for TBX2 and TBX2-AS1. Together these 469 genes contribute to the proliferative state of NBL cells and could have potential as novel therapeutic 470 targets.

$471 \quad$ Altogether, this study provides a comprehensive characterization of IncRNAs across pediatric 472 cancers and serves as a rich resource for future mechanistic studies; these data may aid in the selection 473 of cancer biomarkers and candidate therapeutic IncRNA targets. 
bioRxiv preprint doi: https://doi.org/10.1101/2020.12.10.420257; this version posted April 7, 2021. The copyright holder for this preprint (which

was not certified by peer review) is the author/funder, who has granted bioRxiv a license to display the preprint in perpetuity. It is made available under ACC-BY-NC-ND 4.0 International license.

Pan-pediatric cancer IncRNA study

Modi et al.

480

481

482

483

484

485

\section{Online Methods}

RNA-seq data processing. A comprehensive RNA-seq analysis pipeline was used on all samples (Supplementary Table 1, Supplementary Fig 1). First FASTQC was run on all samples and any samples that had a Phred score $<30$ for more than $25 \%$ of read bases were removed. Samples were then aligned using STAR_2.4.2a ${ }^{85}$ with the following parameters: "STAR -runMode alignReads --runThreadN 10 -twopassMode Basic --twopass1 readsN -1 --chimSegmentMin 15 --chimOutType WithinBAM -genomeDir X--genomeFastaFiles ucsc.hg19.fa --readFilesIn fasta1 fasta2 --readFilesCommand zcat --outSAMtype BAM SortedByCoordinate --outFileNamePrefix X --outSAMstrandField intronMotif --quantMode TranscriptomeSAM GeneCounts --sjdbGTFfile gencode.v19.annotation.gtf --sjdbOverhang X." To assess the quality of the aligned RNA-seq data we ran MultiQC ${ }^{86}$, and removed samples with $<70 \%$ uniquely mapped reads and $<10$ million mapped reads.

Gene/transcript mapping and quantification. To map reads to genes and quantify gene expression we ran StringTie 1.3.3 ${ }^{37}$. StringTie involves three steps, first quantifying expression of both known and novel gene transcripts using an annotation guided approach. We used the Gencode v19 gene annotation to guide gene detection.1) "stringtie bamfile -G gencode.v19.annotation_stringtie.gtf -B --rf -o out.gtf -A gene_abund.tab -C cov_refs.gtf -p 10. " In the second step, String Tie merges the gene annotation across all samples such that there is a uniform annotation for known and novel gene transcripts in one transcriptome gtf file. 2) "stringtie All_PanTARGET_PreMerge_StringTie_Files.txt --merge -G gencode.v19.annotation_stringtie.gtf $\quad-0 \quad$ StringTie_PanCancer_AllMergedTranscripts.gtf." Finally, StringTie is run again to quantify expression using the PanTarget transcriptome gff file and de novo gene transcript detection is turned off. 3) "stringtie bamfile -G StringTie_PanCancer_AllMergedTranscripts.gtf -B -e --rf -o out.gtf -A gene_abund.tab -C cov_refs.gtf -p 10" 
bioRxiv preprint doi: https://doi.org/10.1101/2020.12.10.420257; this version posted April 7, 2021. The copyright holder for this preprint (which

was not certified by peer review) is the author/funder, who has granted bioRxiv a license to display the preprint in perpetuity. It is made available under aCC-BY-NC-ND 4.0 International license.

Pan-pediatric cancer IncRNA study

Modi et al.

505 Comparison of pan-TARGET transcriptome with reference annotation. Novel transcripts were

506 assigned as an isoform of a known gene based on exonic overlap ( $>50 \%$ by bp) with genes in either the

507 GENCODE v19 or RefSeq v74 databases using custom Python scripts. Any remaining novel transcripts

508 were assigned as novel genes (MSTRG_Merged.\# or MSTRG.\#) based on overlapping exon positions.

509 Novel genes were further filtered based on read coverage, in that we required that at least one transcript

510 for a novel gene have more than one exon with at least 5 reads in at least $20 \%$ of samples per cancer.

511 High confidence novel genes were required to have at least 3 exons. Finally, for all transcripts (known

512 and novel), to obtain gene level quantification, transcript FPKM and count values were summed to get a

513 gene level value.

515 Prediction of novel gene coding potential and IncRNA gene annotation. We predicted coding 516 potential of novel transcripts using the PLEK v1 algorithm tool ${ }^{39}$. PLEK uses a support vector machine 517 (SVM) for a binary classification model to distinguish a IncRNA versus a coding mRNA. The features 518 used as input for the SVM are calibrated k-mer usage frequencies of a transcript's sequence. PLEK has 519 previously been validated on RefSeq mRNAs and GENCODE IncRNAs (the main reference annotations 520 used in our study) and has achieved $>90 \%$ accuracy in predicting gene coding potential ${ }^{39}$. To further 521 delineate IncRNAs, we removed any predicted novel non-coding transcripts that were $<200 \mathrm{bp}$ (sum of 522 total exon length). We updated the gene type of GENCODE v19 genes with the gene type of genes that 523 had matching gene names in GENCODE v29. Additionally we filtered out IncRNA genes that have been 524 deprecated in Gencode v29. Finally, some IncRNA genes in Gencode v19, have both a IncRNA and small 525 RNA transcript. For these 147 cases we did not include the small RNA transcript when summing gene 526 transcripts to obtain gene level expression.

528 Tissue specific gene expression. The tau score, a measure of the tissue specific expression of a gene 529 was calculated as described by Yanai et. $\mathrm{al}^{41}$. The formula for the score is listed below. $\mathrm{x}_{\mathrm{i}}$ is defined as 
bioRxiv preprint doi: https://doi.org/10.1101/2020.12.10.420257; this version posted April 7, 2021. The copyright holder for this preprint (which

was not certified by peer review) is the author/funder, who has granted bioRxiv a license to display the preprint in perpetuity. It is made available under ACC-BY-NC-ND 4.0 International license.

Pan-pediatric cancer IncRNA study

Modi et al.

530 the mean expression of a gene in a particular cancer and $\mathrm{n}$ is the total number of cancers considered, in

531 this case $n=6$.

$$
\tau=\frac{\sum_{i=1}^{n}\left(1-\hat{x}_{i}\right)}{n-1} ; \hat{x}_{i}=\frac{x_{i}}{\max _{1 \leq x \leq n}\left(x_{i}\right)}
$$

532

533 CNV detection, processing, and impact on gene expression. Copy number calls were made by 534 Complete Genomics (CGI) from WGS for NBL, WT, AML, and B-ALL. We used CGI 535 files"somaticCnvDetailsDiploidBeta" containing ploidy estimates and tumor/blood coverage along $2 \mathrm{~kb}$ 536 bins across the genome. To create segmentation files, we used custom scripts to reformat CGI coverage 537 data to meet requirements of the "copynumber" $\mathrm{R}$ bioconductor package as previously described ${ }^{44}$. We 538 used the winsorize function in this package, which performs data smoothing and segmentation via a 539 piecewise constant segmentation (pcf) algorithm ( $\mathrm{kmin}=2$ and gamma= 1000). Segmentation files were 540 visualized using the $R$ package svpluscnv (https://github.com/ccbiolab/svpluscnv) 541 https://doi.org/10.1093/bioinformatics/btaa878. We then ran GISTIC2.0, using segmentation data as 542 inputs and parameters: "GISTIC2 -v 30 -refgene hg19 -genegistic 1 -smallmem 1 -broad 1 -twoside 1 543 brlen 0.98 -conf 0.90 -armpeel 1 -savegene 1 -gcm extreme -js 2 -rx 0". To determine which genes copy 544 number impacts, we intersected CNV regions listed in the "all_lesions.conf_90.txt" file from GISTIC output 545 with gene positions. We used section 1 from the "all_lesions.conf_90.txt" file to assign a binary descriptor 546 to each gene as either being not amplified or deleted (CNV-no) if the sample had actual copy gain 0 for 547 the region containing the gene. We assigned CNV-yes if the region containing the gene was amplified or 548 deleted, which included samples with actual copy gain 1 or 2, where 1 indicates low level copy number 549 aberration (exceeds low threshold of copy number: 1: $0.1<\mathrm{t}<0.9$ ) and 2 indicates a high level of copy 550 number aberration, CNV exceeds high threshold $(t>0.9)$ according to GISTIC. To determine CNV impact 551 on gene expression, we assessed differential expression of the gene in samples from the two groups 552 (CNV yes or no) using Wilcoxon rank sum test $(p<0.01)$. Genes were considered to have evidence of 
bioRxiv preprint doi: https://doi.org/10.1101/2020.12.10.420257; this version posted April 7, 2021. The copyright holder for this preprint (which

was not certified by peer review) is the author/funder, who has granted bioRxiv a license to display the preprint in perpetuity. It is made available under aCC-BY-NC-ND 4.0 International license.

Pan-pediatric cancer IncRNA study

Modi et al.

553 differential expression due to copy number if the absolute value of the log2 fold change between the two

554 groups was $>0.58$ and $p<0.05$.

Structural variant detection and filtering. Structural variants were identified from WGS as previously described $^{44}$. Somatic sequence junctions that were completely absent in the normal genome are reported by Complete Genomics (CGI) in the somaticAllJunctionsBeta file. To obtain a high confidence set of junctions, where there is a likely true physical connection between the left and right sections of a junction, the following filtering was applied by CGI to obtain the highConfidenceSomaticAllJunctionsBeta.

1) DiscordantMatePairAlignments $\geq 10$ (10 or more discordant mate pairs in cluster

2) JunctionSequenceResolve $=Y$ (local de novo assembly is successful)

3) Exclude interchromosomal junction if present in any genomes in baseline samples (FrequencylnBaseline $>0$ )

571 Further filtering of these high confidence structural variants included removing rare/common germline

4) Exclude the junction if overlap with known underrepresented repeats $($ KnownUnderrepresentedRepeat $=\mathrm{Y})$ : ALR/Alpha, GAATGn, HSATII, LSU_rRNA_Hsa, and RSU_rRNA_Hsa

variants that passed the CGI filters. We used the Database of Genomic Variants (DGV v. 2016-05-15, GRCh37) in order to remove SVs that had at least $50 \%$ reciprocal overlap with DGV annotated common

Structural variant analysis. To obtain a comprehensive landscape of SVs we combined both the sequence junction and copy number read depth approaches to identify SVs, with co-localizing break points being orthogonally validated. Recurrence of SVs was considered based on overlap with genes from our pan-pediatric cancer transcriptome. Genomic overlap between SVs and genes was determined using the bedtools intersect tool (default parameters). Variants were assigned to genes based on if the 
bioRxiv preprint doi: https://doi.org/10.1101/2020.12.10.420257; this version posted April 7, 2021. The copyright holder for this preprint (which was not certified by peer review) is the author/funder, who has granted bioRxiv a license to display the preprint in perpetuity. It is made available under aCC-BY-NC-ND 4.0 International license.

Pan-pediatric cancer IncRNA study

Modi et al.

581 sequence junction (left/right position) +100 bp overlapped gene coordinates $+/-2.5 \mathrm{~kb}$. Genes were then

582 ranked based on the number of unique samples per cancer with a SV breakpoint.

584 Gene signature analysis. We obtained a list of genes associated with the mesenchymal (MES) and 585 adrenergic (ADRN) NBL cell types from GEO (GSE90805). We then used the GSVA R package ${ }^{67}$ with 586 the Poisson kernel (kcdf) parameter to assign a score per sample representing the total expression 587 enrichment of genes associated with either the MES or ADRN cell types. We performed hierarchical 588 clustering to divide NBL samples into three groups (MES, ADRN or mixed phenotype) based on 589 expression of MES and ADRN genes using the pheatmap R package and cutting the dendrogram at $n=3$. 590 We correlated the MES and ADRN score with IncRNA expression across Stage 4 NBL TARGET cohort 591 and GMKF cohort samples separately and identified IncRNAs as having significant correlation based on 592 absolute value Spearman's rho > 0.6. These IncRNAs were then labeled as MES or ADRN based on 593 significant correlation with either the MES or ADRN score. We next repeated score correlation with PCGs. 594 We performed a guilt-by-association analysis assigning MES/ADRN PCGs and by association their correlated MES/ADRN IncRNAs (Spearman rho > 0.5) to pathways using Fisher exact test, FDR < 0.1 for gene sets in the gene ontology (GO) biological processes collection.

ChIP-seq data analysis. To determine which IncRNAs are regulated by transcription factors involved in 599 the core regulatory circuitry (CRC) we utilized previously generated and analyzed histone and 600 transcription factor ChIP-sequencing data for NBL and T-ALL. For NBL, we used peak files for our 601 previously generated histone ChIP-seq data of: H3K27ac, H3K4me1, H3K4me3 for the BE(2)C cell line ${ }^{87}$, 602 available on GEO: GSE138315. We downloaded raw sequencing files for CRC transcription factor ChIP603 seq data for MYCN, PHOX2B, HAND2, GATA3, TBX2, and ISL1 for the BE(2)C and KELLY cell lines 604 from GEO: GSE94822 $2^{69}$ and selected peaks with q-value < 0.001 for further analysis. We identified 605 regions in the genome where at least $4 / 6$ of the transcription factors overlapped. This was obtained using 606 the homer mergePeaks tool: "mergePeaks -d 1000 -cobound 6 bed_file1... bed_file6" and the resulting 
bioRxiv preprint doi: https://doi.org/10.1101/2020.12.10.420257; this version posted April 7, 2021. The copyright holder for this preprint (which

was not certified by peer review) is the author/funder, who has granted bioRxiv a license to display the preprint in perpetuity. It is made available under aCC-BY-NC-ND 4.0 International license.

Pan-pediatric cancer IncRNA study

Modi et al.

607 coBoundBy4 output file. For the T-ALL CRC we obtained overlapping CRC transcription factor loci for 608 TAL1, GATA3, and RUNX1 from the study by Sanda et. $\mathrm{al}^{71}$, GEO: GSE29181 for both the Jurkat and 609 CCRF-CEM cell lines and integrated ChIP-seq data for the MYB transcription factor from GEO: 610 GSE59657 ${ }^{70}$, only available in the Jurkat line. We selected loci for further analysis if they were bound by 611 TAL1, GATA3, and RUNX1 as previously annotated by Sanda et. al.

Identification of CRC transcription factor regulated genes. To identify genes regulated by the NBL or T-ALL CRC we considered CRC TF binding at both the gene's promoter and other regulatory region interacting with the gene's promoter. We first overlapped CRC regions using bedtools intersect with gene 616 transcript promoter regions, which we defined as 3000bp upstream and downstream of the transcripts 617 first exon. For NBL, we then utilized the promoter-focused Capture C data, inclusive of all interactions 618 within $1 \mathrm{Mb}$ on the same chromosome, to identify genomic regions that were both bound by NBL CRC 619 TFs and interacting with a gene's promoter. To determine this, we used bedtools intersect to determine 620 overlap (minimum $1 \mathrm{bp}$ ) between CRC bound loci with loci involved in chromatin interactions. From these 621 regions, we determined which interacting regions corresponded with a IncRNA promoter region. We 622 performed a similar analysis in T-ALL, however we utilized publicly available SMC1 (cohesin) ChIA-PET 623 data available on the ENCODE project to consider chromatin interactions.

625 Promoter-focused Capture C data generation. High resolution promoter-focused Capture C was 626 performed in the neuroblastoma cell line, NB1643, (untreated) in triplicate. Cell fixation, 3C library 627 generation, capture C, and sequencing was performed as described by Chesi et. al (2019) and Su et al 628 (2020). For each replicate, $10^{7}$ fixed cells were centrifuged to cell pellets and split to 6 tubes for a predigestion incubation with $0.3 \%$ SDS, $1 \times$ NEB Dpnll restriction buffer, and $\mathrm{dH} 2 \mathrm{O}$ for $1 \mathrm{hr}$ at $37^{\circ} \mathrm{C}$ shaking at $1,000 \mathrm{rpm}$. A $1.7 \%$ solution of Triton X-100 was added to each tube and shaking was continued for

631 another hour.10 ul of Dpnll (NEB, $50 \mathrm{U} / \mu \mathrm{L}$ ) was added to each sample tube and continued shaking for 2 
bioRxiv preprint doi: https://doi.org/10.1101/2020.12.10.420257; this version posted April 7, 2021. The copyright holder for this preprint (which was not certified by peer review) is the author/funder, who has granted bioRxiv a license to display the preprint in perpetuity. It is made available under aCC-BY-NC-ND 4.0 International license.

Pan-pediatric cancer IncRNA study

Modi et al.

633 remaining samples were heat inactivated incubated at $1000 \mathrm{rpm}$ in a MultiTherm for $20 \mathrm{~min}$, at $65^{\circ} \mathrm{C}$ to 634 inactivate the Dpnll, and cooled on ice for 20 additional minutes. Digested samples were ligated with 8 $635 \mathrm{uL}$ of T4 DNA ligase (HC ThermoFisher, $30 \mathrm{U} / \mu \mathrm{L})$ and $1 \mathrm{X}$ ligase buffer at 1,000 rpm overnight at $16^{\circ} \mathrm{C}$ 636 .The ligated samples were then de-crosslinked overnight at $65^{\circ} \mathrm{C}$ with Proteinase $\mathrm{K}(20 \mathrm{mg} / \mathrm{mL}$, Denville 637 Scientific) along with pre-digestion and digestion control. Both controls and ligated samples were 638 incubated for $30 \mathrm{~min}$ at $37^{\circ} \mathrm{C}$ with RNase A (Millipore), followed by phenol/chloroform extraction, ethanol 639 precipitation at $-20^{\circ} \mathrm{C}$, then the $3 \mathrm{C}$ libraries were centrifuged at $3000 \mathrm{rpm}$ for $45 \mathrm{~min}$ at $4^{\circ} \mathrm{C}$ to pellet the 640 samples. The pellets of $3 \mathrm{C}$ libraries and controls were resuspended in $300 \mathrm{uL}$ and $20 \mu \mathrm{L} \mathrm{dH} 2 \mathrm{O}$, 641 respectively, and stored at $-20^{\circ} \mathrm{C}$. Sample concentrations were measured by Qubit. Digestion and 642 ligation efficiencies were assessed by gel electrophoresis on a $0.9 \%$ agarose gel and also by quantitative 643 PCR (SYBR green, Thermo Fisher).

Isolated DNA from 3C libraries was quantified using a Qubit fluorometer (Life technologies), and

$64510 \mu \mathrm{g}$ of each library was sheared in $\mathrm{dH} 2 \mathrm{O}$ using a QSonica Q800R to an average fragment size of 350bp.QSonica settings used were $60 \%$ amplitude, 30s on, 30s off, 2 min intervals, for a total of 5 647 intervals at $4{ }^{\circ} \mathrm{C}$. After shearing, DNA was purified using AMPureXP beads (Agencourt). DNA size was assessed on a Bioanalyzer 2100 using a DNA 1000 Chip (Agilent) and DNA concentration was checked via Qubit. SureSelect XT library prep kits (Agilent) were used to repair DNA ends and for adaptor ligation 650 following the manufacturer protocol. Excess adaptors were removed using AMPureXP beads. Size and 651 concentration were checked again by Bioanalyzer 2100 using a DNA 1000 Chip and by Qubit fluorometer 652 before hybridization. One microgram of adaptor-ligated library was used as input for the SureSelect XT 653 capture kit using manufacturer protocol and custom-designed $41 \mathrm{~K}$ promoter Capture-C probe set. The 654 quantity and quality of the captured libraries were assessed by Bioanalyzer using a high sensitivity DNA 655 Chip and by Qubit fluorometer. SureSelect XT libraries were then paired-end sequenced on Illumina 656 NovaSeq 6000 platform (51bp read length) at the Center for Spatial and Functional Genomics at CHOP. 
bioRxiv preprint doi: https://doi.org/10.1101/2020.12.10.420257; this version posted April 7, 2021. The copyright holder for this preprint (which was not certified by peer review) is the author/funder, who has granted bioRxiv a license to display the preprint in perpetuity. It is made available under aCC-BY-NC-ND 4.0 International license.

Pan-pediatric cancer IncRNA study

Modi et al.

Promoter-focused Capture C data analysis. Paired-end reads from each replicated were preprocessed using the HICUP pipeline (v0.5.9), with bowtie2 as aligner and hg19 as the reference genome. The unique ditags output from HiCUP were further processed by the chicagoTools bam2chicago.sh script before significant promoter interaction calling. Significant promoter interactions at 1-Dpnll fragment resolution were called using CHiCAGO (v1.1.8) with default parameters except for binsize set to 2500. Significant interactions at 4-Dpnll fragment resolution were also called using CHiCAGO with artificial baitmap and rmap files in which Dpnll fragments were concatenated in silico into 4 consecutive fragments using default parameters except for removeAdjacent set to False. Interactions with a CHiCAGO score > 5 in either 1-fragment or 4-fragment resolution were considered as significant interactions. The significant interactions were finally converted to ibed format in which each line represents a physical interaction between fragments.

Differential gene expression analysis for T-ALL subtypes. We identified differentially expressed genes using the DESeq2 tool. We compared expression between the TAL1 subgroup and non-TAL1 subgroup, defined by Liu, et $\mathrm{al}^{75}$. We ran DESeq2 using default parameters and considered genes as significantly differentially expressed if their absolute value of the log 2 fold change was $>0.58$ and their Benjamini-Hoschberg adjusted-p value was $<0.01$.

IncMod implementation: transcription factor target gene regulation. We developed custom Python scripts to implement the general framework of the IncMod method. The first part of this framework involved determining transcription factor target gene regulation specific to each cancer. Target genes here are defined as any protein coding or IncRNA gene and excludes pseduogenes and small RNAs. Given that ChIP-seq binding profiles for the majority of transcription factors were not available for tissues associated with each of these cancers we instead used transcription factor motif analysis as a proxy. We utilized motifs in the JASPAR database ${ }^{88}$ and predictions of binding across the genome determined by FIMO and available in the UCSC genome database: 
bioRxiv preprint doi: https://doi.org/10.1101/2020.12.10.420257; this version posted April 7, 2021. The copyright holder for this preprint (which

was not certified by peer review) is the author/funder, who has granted bioRxiv a license to display the preprint in perpetuity. It is made available under ACC-BY-NC-ND 4.0 International license.

Pan-pediatric cancer IncRNA study

Modi et al.

http://expdata.cmmt.ubc.ca/JASPAR/downloads/UCSC tracks/2018/hg19/tsv/. For each

685 transcript we determined potential regulatory transcription factors based on the presence of predicted binding motifs in the gene promoter region. Promoter regions were defined as regions 3000 bp upstream and downstream of the transcript's first exon. Next we selected transcription factors based on their expression in each cancer and then performed linear regression considering the expression of the transcription factor and target gene specific to each cancer. We adjusted the false discovery rate due to multiple testing using the Benjamini-Hochberg method and selected TF-target gene pairs with

691 significantly associated expression (adjusted $p$-value $<1 e-5$ ).

Identification of IncRNA modulators. To identify transcriptional perturbation, we first delineated genes

694 (TF, target genes, or IncRNAs) that had high expression variance (IQR > 1.5). For each differentially 695 expressed IncRNA in each cancer we calculated the following, as has been done in previous 696 studies $^{21,22,56}$. For a given cancer and given IncRNA we sorted samples in the cancer based on the given 697 IncRNAs expression (low to high). We then determined the correlation (Spearman's rho) between the 698 expression of all transcription factor and target gene pairs previously identified in the given cancer. This 699 correlation was calculated for the $25 \%$ of samples with the lowest IncRNA expression and separately for 700 the $25 \%$ of samples with the highest expression for the given IncRNA. To ensure that we observed TF701 target gene regulation we required that the correlation between the TF-target pair in either the low or high 702 IncRNA expressing group was at least $\mathrm{R}>0.4$. We only further evaluated the IncRNA TF-target gene 703 triplet if the correlation difference between the low and high IncRNA expression group was $R>0.45$. To 704 formally compare the correlation difference we first normalized the correlation using the Fisher $r$ to $z$ 705 transformation. Then we calculated the rewiring score, z-statistic, as previously described ${ }^{21}$, which is 706 used to describe the degree of regulation change between the TF and target gene.

$$
F(R)=\frac{1}{2} \ln \frac{1+R}{1-R}
$$


bioRxiv preprint doi: https://doi.org/10.1101/2020.12.10.420257; this version posted April 7, 2021. The copyright holder for this preprint (which

was not certified by peer review) is the author/funder, who has granted bioRxiv a license to display the preprint in perpetuity. It is made available under ACC-BY-NC-ND 4.0 International license.

Pan-pediatric cancer IncRNA study

Modi et al.

708

$$
\text { rewire }_{T F-\text { gene }}=P\left(|X| \leq\left|\frac{F\left(R_{\text {high }}\right)-F\left(R_{\text {low }}\right)}{\sqrt{\frac{1.06}{n_{\text {high }}-3}+\frac{1.06}{n_{\text {low }}-3}}}\right|\right), X \sim N(0,1)
$$

As a departure from what is described by Li et. al (IncMod method) ${ }^{56}$, we used permutation analysis to robustly assess the significance of the rewire score in the context of multiple hypothesis testing as described by Sham et. $\mathrm{al}^{89,90}$. We randomly shuffled target gene expression (TF-target gene pair labels) and calculated the rewire score $P$ value across all TF-target gene pairs per given IncRNA. We kept the smallest observed $\mathrm{P}$ value and repeated the permutation 100 times. This empirical frequency distribution of the smallest $P$ values was then compared to the $P$ value in our real data to calculate an empirical adjusted $P$ value (adj $P$ value) as given by the formula below, where $r$ is the number of permutations where the smallest $P$ value are less than our actual $P$ value and $n$ is the number of permutations.

$$
\text { adj } \text { Pvalue }_{j}=\frac{1+\left(\# \text { permutations where } q \leq p_{j}\right)}{1+(\# \text { permutations })}
$$

The IncRNA-TF-target gene triplets, with adjusted $p<0.1$ were considered significant. Datasets with smaller sample sizes had lower statistical power and thus fewer significant triplets. Triplets were then classified into three patterns based on correlation changes between the low and high expressing IncRNA group: increased correlation - enhanced, decreased correlation - attenuated, and inverted - positive to negative correlation and vice versa. We annotated IncRNA target genes as cancer genes based on if they were listed in the COSMIC database or a complied list from Chiu et. $\mathrm{al}^{22}$.

Cell lines and reagents. NBL cell lines were obtained from the American Type Tissue Culture Collection (ATCC) and grown in RPM1-1640 with HEPES, L-glutamine and phenol red, supplemented with 10\% FBS, $1 \%$ L-glutamine in an incubator at $37^{\circ} \mathrm{C}$ with $5 \% \mathrm{CO}_{2}$. Cell line identity was confirmed biennially through genotyping and confirmation of STR (short tandem repeat) profiles, while routine testing for Mycoplasma contamination was confirmed to be negative. 
bioRxiv preprint doi: https://doi.org/10.1101/2020.12.10.420257; this version posted April 7, 2021. The copyright holder for this preprint (which was not certified by peer review) is the author/funder, who has granted bioRxiv a license to display the preprint in perpetuity. It is made available under aCC-BY-NC-ND 4.0 International license.

Pan-pediatric cancer IncRNA study

Modi et al.

731 siRNA and growth assays. The NBL cell lines, NLF and SKNSH, were plated in a 96-well RTCES

732 microelectronic sensor array (ACEA Biosciences, San Diego, CA, USA). Cell density measurements

733 were made every hour and were normalized to 24 hours post-plating (at transfection time). We used

734 siRNAs to knockdown the expression of genes in NLF and SKNSH. The siRNAs utilized were either a 735 non-targeting negative control siRNA (Silencer ${ }^{T M}$ Select Negative Control siRNA, cat \#4390843), TBX2-

736 AS1 Silencer ${ }^{\mathrm{TM}}$ Select siRNA (cat \# n514841), and SMARTpool: ON-TARGETplus PLK1 siRNA (cat \# L-

737 003290-00-0010). Transfection of cells was done using the DharmaFECT 1 transfection reagent (cat \#

738 T-2001-02). siRNA at a concentration of 50nM and $2 \%$ (NLF) and $4 \%$ (SKNSH) DharmaFECT was added

739 to RPMI medium without $10 \%$ FBS or any antibiotic separately and then incubated at room temperature

740 for 5 minutes. The siRNA medium was then added to the DharmaFECT and incubated for another 20

741 minutes to form a complex. This solution was then mixed with our normal growth media and applied to

742 cells 24 hours after they had been initially plated. All experiments were repeated in triplicate, with

743 technical replicates $(n=3)$ being averaged per biological replicate.

Real time quantitative PCR. Total RNA was extracted from NBL cells using miRNeasy kit (Qiagen) and

the provided protocol for animal cells. The concentration of RNA was determined with the Nanodrop (Thermo Scientific). cDNA synthesis was performed using the SuperScript ${ }^{\mathrm{TM}}$ First-Strand Synthesis System for RT-PCR using the SuperScript ${ }^{\mathrm{TM}}$ reverse transcriptase (Invitrogen). 5-20ng of cDNA were mixed with the TaqMan Universal PCR Master Mix (Thermo Fisher Scientific) and TaqMan probes/primers for either TBX2-AS1 (Hs00417285_m1) or the house keeping gene, HPRT1 751 (Hs02800695_m1). Gene expression from these reactions were measured using RT-qPCR and TBX2752 AS1 expression was normalized to HPRT1 expression.

NLF gene knockdown expression profiling. Total RNA was isolated from the NLF cell line 48 hours post treatment with siTBX2-AS1 and non-targeting control samples, siNTC, (three biological replicates per condition) and $1000 \mathrm{ng} / \mathrm{sample}$ was used as input for library preparation with the TruSeq Stranded 
bioRxiv preprint doi: https://doi.org/10.1101/2020.12.10.420257; this version posted April 7, 2021. The copyright holder for this preprint (which

was not certified by peer review) is the author/funder, who has granted bioRxiv a license to display the preprint in perpetuity. It is made available under aCC-BY-NC-ND 4.0 International license.

Pan-pediatric cancer IncRNA study

Modi et al.

mRNA Sample Prep Kit from Illumina (with Ribo-Zero treatment). RNA-seq libraries were sequenced on the Nextseq 500 at depth 10 million reads per sample minimum. Library prep and sequencing was performed by the Sidney Kimmel Cancer Center Genomics Facility of Thomas Jefferson University. Sample and read quality was assessed using FastQC and reads were aligned and mapped using the same methods as described above for TARGET cancer samples. Genes were retained if at least one sample had expression greater than 0 FPKM. To identify differentially expressed genes between siNTC and siTBX2-AS1 treated cells, we used the DESeq2 method with default parameters. Differentially expressed genes were annotated based on absolute value log fold change $>1.5$ and Benjamini-Hochberg adjusted $p$-value $<0.1$. Gene set enrichment analysis (GSEA) was performed across samples using the MsigDB Hallmarks gene sets and significantly enriched gene sets with FDR q-val $<0.1$ were retained. Up-stream co-regulators of differentially expressed genes were identified using default parameters from the iRegulon program part of the Cytoscape suite.

\section{Data Availability}

All TARGET RNA and DNA-sequencing data analyzed in this study are available through the database of Genotypes and Phenotypes (dbGaP; https://www.ncbi.nlm.nih.gov/gap/) under study-id phs000218 and accession number phs000467. GMKF RNA-sequencing data are available through dbGAP study accession phs001436.v1.p1. Neuroblastoma cell line RNA-sequencing data analyzed in this study are available through GEO at accessions GSE89413. NBL histone ChIP-seq and transcription factor ChIPseq data used in this study are both available through GEO at accessions: GSE138315 and GSE94822, respectively. T-ALL transcription factor ChIP-seq data and SMC1 ChIA-PET data are available through GEO at accessions GSE29181, GSE59657, and GSE68977.

\section{Acknowledgements}

This work was supported in part by NIH grants R01-CA124709 (S.J.D.), R03 CA230366 (S.J.D.), X01 HL136997 (J.M.M.), and T32-HG46-18 (A.M.). This project was also funded in part by a supplement to 
bioRxiv preprint doi: https://doi.org/10.1101/2020.12.10.420257; this version posted April 7, 2021. The copyright holder for this preprint (which was not certified by peer review) is the author/funder, who has granted bioRxiv a license to display the preprint in perpetuity. It is made

Pan-pediatric cancer IncRNA study

Modi et al.

786 the Children's Oncology Group Chair's grant CA098543 and with federal funds from the National Cancer

787 Institute, National Institutes of Health, under Contract No. HHSN261200800001E to S.J.D and Complete

788 Genomics. Promoter Capture C studies were funded by the Center for Spatial and Functional Genomics

789 (A.D.W and S.FA.G) at CHOP. S.FA.G. was supported by the Daniel B. Burke Endowed and Chair for 790 Diabetes Research and R01 HG010067.

\section{Author Contributions}

A.M. and S.J.D. conceived and designed the study. M.A.S., J.M.G.A, D.S.G., E.J.P, S.M., S.P.H., S.J.D. 796 and J.M.M. generated the TARGET data. K.L.C., M.E.J., S.J.D., A.D.W. and S.F.A.G. generated 797 promoter-focused capture C data. E.M. C.S, and A.M. analyzed promoter-focused capture C data. A.M., 798 G.L., S.R. analyzed TARGET data. A.M., K.L.C., T.C.L. and D.C. performed TBX2-AS1 experiments. 799 S.J.D. supervised the study. A.M. and S.J.D drafted the manuscript. All authors edited and approved the 800 manuscript.

801

802

803 
bioRxiv preprint doi: https://doi.org/10.1101/2020.12.10.420257; this version posted April 7, 2021. The copyright holder for this preprint (which was not certified by peer review) is the author/funder, who has granted bioRxiv a license to display the preprint in perpetuity. It is made available under aCC-BY-NC-ND 4.0 International license.

Pan-pediatric cancer IncRNA study

Modi et al.

804

805

806

807

808

809

810

811

812

813

814

815

816

\section{References}

1. Rinn, J.L. \& Chang, H.Y. Genome regulation by long noncoding RNAs. Annu Rev Biochem 81, 145-66 (2012).

2. Bonasio, R. \& Shiekhattar, R. Regulation of transcription by long noncoding RNAs. Annual review of genetics 48, 433-55 (2014).

3. Iyer, M.K. et al. The landscape of long noncoding RNAs in the human transcriptome. Nature genetics 47, 199-208 (2015).

4. Gil, N. \& Ulitsky, I. Regulation of gene expression by cis-acting long non-coding RNAs. Nat Rev Genet 21, 102-117 (2020).

5. Dykes, I.M. \& Emanueli, C. Transcriptional and Post-transcriptional Gene Regulation by Long Non-coding RNA. Genomics Proteomics Bioinformatics 15, 177-186 (2017).

6. Marchese, F.P., Raimondi, I. \& Huarte, M. The multidimensional mechanisms of long noncoding RNA function. Genome Biol 18, 206 (2017).

7. Villegas, V.E. \& Zaphiropoulos, P.G. Neighboring gene regulation by antisense long non-coding RNAs. International journal of molecular sciences 16, 3251-66 (2015).

8. Kopp, F. \& Mendell, J.T. Functional Classification and Experimental Dissection of Long Noncoding RNAs. Cell 172, 393-407 (2018).

9. Kotake, Y. et al. Long non-coding RNA ANRIL is required for the PRC2 recruitment to and silencing of p15(INK4B) tumor suppressor gene. Oncogene 30, 1956-62 (2011).

10. Engreitz, J.M. et al. The Xist IncRNA exploits three-dimensional genome architecture to spread across the X chromosome. Science $\mathbf{3 4 1}, 1237973$ (2013).

11. Tripathi, $\mathrm{V}$. et al. The nuclear-retained noncoding RNA MALAT1 regulates alternative splicing by modulating SR splicing factor phosphorylation. Mol Cell 39, 925-38 (2010).

12. Perry, R.B. \& Ulitsky, I. The functions of long noncoding RNAs in development and stem cells. Development 143, 3882-3894 (2016).

13. Monnier, P. et al. H19 IncRNA controls gene expression of the Imprinted Gene Network by recruiting MBD1. Proc Natl Acad Sci U S A 110, 20693-8 (2013).

14. Lin, N. et al. An evolutionarily conserved long noncoding RNA TUNA controls pluripotency and neural lineage commitment. Mol Cell 53, 1005-19 (2014).

15. Yan, X. et al. Comprehensive Genomic Characterization of Long Non-coding RNAs across Human Cancers. Cancer Cell 28, 529-540 (2015).

16. Du, Z. et al. Integrative genomic analyses reveal clinically relevant long noncoding RNAs in human cancer. Nat Struct Mol Biol 20, 908-13 (2013).

17. Lanzós, A. et al. Discovery of Cancer Driver Long Noncoding RNAs across 1112 Tumour Genomes: New Candidates and Distinguishing Features. Scientific Reports 7, 1-16 (2017).

18. Wang, Y. et al. Discovery and validation of the tumor-suppressive function of long noncoding RNA PANDA in human diffuse large B-cell lymphoma through the inactivation of MAPK/ERK signaling pathway. Oncotarget 8, 72182-72196 (2017).

19. Hajjari, M. \& Salavaty, A. HOTAIR: an oncogenic long non-coding RNA in different cancers. Cancer Biol Med 12, 1-9 (2015).

20. Onagoruwa, O.T., Pal, G., Ochu, C. \& Ogunwobi, O.O. Oncogenic Role of PVT1 and Therapeutic Implications. Front Oncol 10, 17 (2020).

21. Li, Y. et al. LncMAP: Pan-cancer Atlas of long noncoding RNA-mediated transcriptional network perturbations. Nucleic Acids Research 46, 1113-1123 (2018).

22. Chiu, H.S. et al. Pan-Cancer Analysis of IncRNA Regulation Supports Their Targeting of Cancer Genes in Each Tumor Context. Cell Rep 23, 297-312 e12 (2018).

23. Huarte, M. The emerging role of IncRNAs in cancer. Nature medicine 21, 1253-61 (2015).

24. Xu, Y. et al. Identification and comprehensive characterization of IncRNAs with copy number variations and their driving transcriptional perturbed subpathways reveal functional significance for cancer. Brief Bioinform (2019). 
bioRxiv preprint doi: https://doi.org/10.1101/2020.12.10.420257; this version posted April 7, 2021. The copyright holder for this preprint (which was not certified by peer review) is the author/funder, who has granted bioRxiv a license to display the preprint in perpetuity. It is made available under aCC-BY-NC-ND 4.0 International license.

Pan-pediatric cancer IncRNA study

Modi et al.

855

856

857

858

859

860

861

862

863

864

865

866

867

868

869

870

871

872

873

874

875

876

877

878

879

880

881

882

883

884

885

886

887

888

889

890

891

892

893

894

895

896

897

898

899

900

901

902

903

25. Mondal, T. et al. Sense-Antisense IncRNA Pair Encoded by Locus $6 \mathrm{p} 22.3$ Determines Neuroblastoma Susceptibility via the USP36-CHD7-SOX9 Regulatory Axis. Cancer Cell 33, 417-434.e7 (2018).

26. Russell, M.R. et al. CASC15-S is a tumor suppressor IncRNA at the $6 \mathrm{p} 22$ neuroblastoma susceptibility locus. Cancer Res 75, 3155-3166 (2016).

27. Pandey, G.K. et al. The Risk-Associated Long Noncoding RNA NBAT-1 Controls Neuroblastoma Progression by Regulating Cell Proliferation and Neuronal Differentiation. Cancer Cell 26, 722-737 (2014).

28. Sahu, D. et al. Co-expression analysis identifies long noncoding RNA SNHG1 as a novel predictor for event-free survival in neuroblastoma. Oncotarget 7, 58022-58037 (2016).

29. Mazar, J. et al. The long non-coding RNA GAS5 differentially regulates cell cycle arrest and apoptosis through activation of BRCA1 and p53 in human neuroblastoma. Oncotarget 5, 65896607 (2016).

30. Rombaut, D. et al. Integrative analysis identifies lincRNAs up- and downstream of neuroblastoma driver genes. Sci Rep 9, 5685 (2019).

31. Ngoc, P.C.T. et al. Identification of novel IncRNAs regulated by the TAL1 complex in T-cell acute lymphoblastic leukemia. Leukemia 32, 2138-2151 (2018).

32. Trimarchi, T. et al. Genome-wide mapping and characterization of Notch-regulated long noncoding RNAs in acute leukemia. Cell 158, 593-606 (2014).

33. Liu, Y., Liu, H. \& Zhang, D. Identification of novel long non-coding RNA in diffuse intrinsic pontine gliomas by expression profile analysis. Oncol Lett 16, 6401-6406 (2018).

34. McDaniel, L.D. et al. Common variants upstream of MLF1 at 3q25 and within CPZ at 4p16 associated with neuroblastoma. PLoS Genet 13, e1006787 (2017).

35. Downing, J.R. et al. The Pediatric Cancer Genome Project. Nat Genet 44, 619-22 (2012).

36. Ma, X. et al. Pan-cancer genome and transcriptome analyses of 1,699 paediatric leukaemias and solid tumours. Nature 555, 371-376 (2018).

37. Pertea, M. et al. StringTie enables improved reconstruction of a transcriptome from RNA-seq reads. Nature biotechnology 33, 290-5 (2015).

38. Frankish, A. et al. GENCODE reference annotation for the human and mouse genomes. Nucleic Acids Res 47, D766-D773 (2019).

39. Li, A., Zhang, J. \& Zhou, Z. PLEK: a tool for predicting long non-coding RNAs and messenger RNAs based on an improved k-mer scheme. BMC Bioinformatics 15, 311 (2014).

40. Consortium, G.T. Human genomics. The Genotype-Tissue Expression (GTEx) pilot analysis: multitissue gene regulation in humans. Science 348, 648-60 (2015).

41. Yanai, I. et al. Genome-wide midrange transcription profiles reveal expression level relationships in human tissue specification. Bioinformatics 21, 650-9 (2005).

42. Kryuchkova-Mostacci, N. \& Robinson-Rechavi, M. A benchmark of gene expression tissuespecificity metrics. Brief Bioinform 18, 205-214 (2017).

43. Dong, K., Tang, W. \& Dong, R. MEG3, HCN3 and linc01105 influence proliferation and apoptosis of neuroblastoma cells via HIF-1 alpha and p53 pathway. Pediatric Blood and Cancer 63, S194 (2016).

44. Lopez, G. et al. Somatic structural variation targets neurodevelopmental genes and identifies SHANK2 as a tumor suppressor in neuroblastoma. Genome Res 30, 1228-1242 (2020).

45. Mermel, C.H. et al. GISTIC2.0 facilitates sensitive and confident localization of the targets of focal somatic copy-number alteration in human cancers. Genome Biol 12, R41 (2011).

46. Pugh, T.J. et al. The genetic landscape of high-risk neuroblastoma. Nat Genet 45, 279-84 (2013).

47. Gadd, S. et al. A Children's Oncology Group and TARGET initiative exploring the genetic landscape of Wilms tumor. Nat Genet 49, 1487-1494 (2017). 
bioRxiv preprint doi: https://doi.org/10.1101/2020.12.10.420257; this version posted April 7, 2021. The copyright holder for this preprint (which was not certified by peer review) is the author/funder, who has granted bioRxiv a license to display the preprint in perpetuity. It is made available under aCC-BY-NC-ND 4.0 International license.

Pan-pediatric cancer IncRNA study

Modi et al.

904 48. Harvey, R.C. et al. Identification of novel cluster groups in pediatric high-risk B-precursor acute

905

906

907

908

909

910

911

912

913

914

915

916

917

918

919

920

921

922

923

924

925

926

927

928

929

930

931

932

933

934

935

936

937

938

939

940

941

942

943

944

945

946

947

948

949

950

951

952 lymphoblastic leukemia with gene expression profiling: correlation with genome-wide DNA copy number alterations, clinical characteristics, and outcome. Blood 116, 4874-84 (2010).

49. Emmrich, S. et al. LincRNAs MONC and MIR100HG act as oncogenes in acute megakaryoblastic leukemia. Mol Cancer 13, 171 (2014).

50. Gruber, T.A. \& Downing, J.R. The biology of pediatric acute megakaryoblastic leukemia. Blood 126, 943-9 (2015).

51. Liu, Y. et al. Genome-wide screening for functional long noncoding RNAs in human cells by Cas9 targeting of splice sites. Nat Biotechnol (2018).

52. Zhao, X. et al. CTCF cooperates with noncoding RNA MYCNOS to promote neuroblastoma progression through facilitating MYCN expression. Oncogene, 1-12 (2015).

53. Ng, S.Y., Bogu, G.K., Soh, B. \& Stanton, L.W. The long noncoding RNA RMST interacts with SOX2 to regulate neurogenesis. Molecular Cell 51, 349-359 (2013).

54. Tseng, Y.Y. et al. PVT1 dependence in cancer with MYC copy-number increase. Nature 512, 82-6 (2014).

55. Jeon, Y. \& Lee, J.T. YY1 tethers Xist RNA to the inactive X nucleation center. Cell 146, 119-33 (2011).

56. $\mathrm{Li}$, Y. et al. Identification and characterization of IncRNA mediated transcriptional dysregulation dictates IncRNA roles in glioblastoma. Oncotarget 7, 45027-45041 (2016).

57. Liberzon, A. et al. The Molecular Signatures Database (MSigDB) hallmark gene set collection. Cell Syst 1, 417-425 (2015).

58. Delgado, M.D. \& Leon, J. Myc roles in hematopoiesis and leukemia. Genes Cancer 1, 605-16 (2010).

59. Amaral, P.P. et al. Genomic positional conservation identifies topological anchor point RNAs linked to developmental loci. Genome Biol 19, 32 (2018).

60. Wang, M. et al. Long noncoding RNA GAS5 promotes bladder cancer cells apoptosis through inhibiting EZH2 transcription. Cell Death Dis 9, 238 (2018).

61. Zhao, Y. et al. Long non-coding RNA (IncRNA) small nucleolar RNA host gene 1 (SNHG1) promote cell proliferation in colorectal cancer by affecting P53. Eur Rev Med Pharmacol Sci 22, 976-984 (2018).

62. Kharabi Masouleh, B. et al. Mechanistic rationale for targeting the unfolded protein response in pre-B acute lymphoblastic leukemia. Proc Natl Acad Sci U S A 111, E2219-28 (2014).

63. Federico, S., Brennan, R. \& Dyer, M.A. Childhood cancer and developmental biology a crucial partnership. Curr Top Dev Biol 94, 1-13 (2011).

64. Cao, J. et al. A human cell atlas of fetal gene expression. Science 370(2020).

65. Boeva, V. et al. Heterogeneity of neuroblastoma cell identity defined by transcriptional circuitries. Nat Genet 49, 1408-1413 (2017).

66. van Groningen, T. et al. Neuroblastoma is composed of two super-enhancer-associated differentiation states. Nat Genet 49, 1261-1266 (2017).

67. Hanzelmann, S., Castelo, R. \& Guinney, J. GSVA: gene set variation analysis for microarray and RNA-seq data. BMC Bioinformatics 14, 7 (2013).

68. Signal, B., Gloss, B.S. \& Dinger, M.E. Computational Approaches for Functional Prediction and Characterisation of Long Noncoding RNAs. Trends in Genetics 32, 620-637 (2016).

69. Durbin, A.D. et al. Selective gene dependencies in MYCN-amplified neuroblastoma include the core transcriptional regulatory circuitry. Nat Genet 50, 1240-1246 (2018).

70. Mansour, M.R. et al. An oncogenic super-enhancer formed through somatic mutation of a noncoding intergenic element. Science 346, 1373-1377 (2014).

71. Sanda, T. et al. Core transcriptional regulatory circuit controlled by the TAL1 complex in human T cell acute lymphoblastic leukemia. Cancer Cell 22, 209-21 (2012). 
bioRxiv preprint doi: https://doi.org/10.1101/2020.12.10.420257; this version posted April 7, 2021. The copyright holder for this preprint (which was not certified by peer review) is the author/funder, who has granted bioRxiv a license to display the preprint in perpetuity. It is made available under aCC-BY-NC-ND 4.0 International license.

Pan-pediatric cancer IncRNA study

Modi et al.

953

954

955

956

957

958

959

960

961

962

963

964

965

966

967

968

969

970

971

972

973

974

975

976

977

978

979

980

981

982

983

984

985

986

987

988

989

990

991

992

72. Verboom, K. et al. A comprehensive inventory of TLX1 controlled long non-coding RNAs in Tcell acute lymphoblastic leukemia through polyA+ and total RNA sequencing. Haematologica 103, e585-e589 (2018).

73. Chesi, A. et al. Genome-scale Capture C promoter interactions implicate effector genes at GWAS loci for bone mineral density. Nat Commun 10, 1260 (2019).

74. Decaesteker, B. et al. TBX2 is a neuroblastoma core regulatory circuitry component enhancing MYCN/FOXM1 reactivation of DREAM targets. Nat Commun 9, 4866 (2018).

75. Liu, Y. et al. The genomic landscape of pediatric and young adult T-lineage acute lymphoblastic leukemia. Nat Genet 49, 1211-1218 (2017).

76. Harenza, J.L. et al. Transcriptomic profiling of 39 commonly-used neuroblastoma cell lines. Sci Data 4, 170033 (2017).

77. Janky, R. et al. iRegulon: from a gene list to a gene regulatory network using large motif and track collections. PLoS Comput Biol 10, e1003731 (2014).

78. Bourdoumis, A. et al. The novel prostate cancer antigen 3 (PCA3) biomarker. Int Braz J Urol 36, 665-8; discussion 669 (2010).

79. Slack, F.J. \& Chinnaiyan, A.M. The Role of Non-coding RNAs in Oncology. Cell 179, 1033-1055 (2019).

80. Chen, Y., Xu, L., Lin, R.Y., Muschen, M. \& Koeffler, H.P. Core transcriptional regulatory circuitries in cancer. Oncogene (2020).

81. Zhang, X. \& Ho, T.T. Computational Analysis of IncRNA Function in Cancer. Methods Mol Biol 1878, 139-155 (2019).

82. Scheibe, M., Butter, F., Hafner, M., Tuschl, T. \& Mann, M. Quantitative mass spectrometry and PAR-CLIP to identify RNA-protein interactions. Nucleic Acids Res 40, 9897-902 (2012).

83. Chu, C., Qu, K., Zhong, F.L., Artandi, S.E. \& Chang, H.Y. Genomic maps of long noncoding RNA occupancy reveal principles of RNA-chromatin interactions. Mol Cell 44, 667-78 (2011).

84. Hon, C.C. et al. An atlas of human long non-coding RNAs with accurate 5' ends. Nature 543, 199-204 (2017).

85. Dobin, A. et al. STAR: ultrafast universal RNA-seq aligner. Bioinformatics 29, 15-21 (2013).

86. Ewels, P., Magnusson, M., Lundin, S. \& Kaller, M. MultiQC: summarize analysis results for multiple tools and samples in a single report. Bioinformatics 32, 3047-8 (2016).

87. Upton, K. et al. Epigenomic profiling of neuroblastoma cell lines. Sci Data 7, 116 (2020).

88. Khan, A. et al. JASPAR 2018: update of the open-access database of transcription factor binding profiles and its web framework. Nucleic Acids Res 46, D260-D266 (2018).

89. Sham, P.C. \& Purcell, S.M. Statistical power and significance testing in large-scale genetic studies. Nat Rev Genet 15, 335-46 (2014).

90. Wagner, B.D., Zerbe, G.O., Mexal, S. \& Leonard, S.S. Permutation-based adjustments for the significance of partial regression coefficients in microarray data analysis. Genet Epidemio/ 32, 18 (2008). 
bioRxiv preprint doi: https://doi.org/10.1101/2020.12.10.420257; this version posted April 7, 2021. The copyright holder for this preprint (which

was not certified by peer review) is the author/funder, who has granted bioRxiv a license to display the preprint in perpetuity. It is made available under ACC-BY-NC-ND 4.0 International license.

Pan-pediatric cancer IncRNA study

Modi et al.

993

994

995

996

\section{FIGURE LEGENDS}

\section{Fig 1: Pan-pediatric transcriptome characterization.}

a. Overview of pan-pediatric cancer RNA-seq dataset and schematic of data processing and filtering. Reads from RNA-seq fastq files were aligned using the STAR algorithm and then gene transcripts were mapped in a guided de novo manner and quantified via the StringTie algorithm. Genes were considered novel if they did not have transcript exon structures matching genes in the GENCODE v19 or RefSeq v74 databases. Novel genes were assigned as IncRNAs based on length $>200 \mathrm{bp}$ and non-coding potential calculated using the PLEK algorithm. Transcripts with low expression (FPKM $<1$ in $>80 \%$ samples) were not considered for further analysis. b. Pie graph showing the quantity of expressed and robustly expressed protein coding genes, GENCODE/RefSeq annotated IncRNAs, and novel IncRNAs. High confidence expressed genes are distinguished from all expressed genes. Adjoining schematic gives overview of additional data types that were integrated with transcriptome data: WGS, ChIP-seq, and chromatin capture. Listed are the analyses used to elucidate IncRNAs with functional roles in pediatric cancer. c. Cumulative expression plots comparing the number of IncRNAs and (d) protein coding genes, respectively, that constitute the total sum of gene expression (FPKM) per pediatric cancer. e. Percentage of total IncRNA expression (FPKM) accounted for by the union of top five expressed IncRNAs per cancer (total 11 IncRNAs).

\section{Fig 2: IncRNAs exhibit tissue specific expression that can distinguish cancers.}

a. Tissue specificity index (tau score) which ranges from 0 (ubiquitously expressed) to 1 (tissue specific) is plotted for genes across three gene types: protein coding genes, IncRNAs, and novel IncRNAs. Table shows the tau score range and mean per gene type. b. Number of tissue specific known and novel IncRNAs in each cancer as defined by tissue specific gene threshold: tau score $>0.8$. c. Heatmap showing the hierarchically clustered gene expression for the top five most tissue specific IncRNAs per 
bioRxiv preprint doi: https://doi.org/10.1101/2020.12.10.420257; this version posted April 7, 2021. The copyright holder for this preprint (which was not certified by peer review) is the author/funder, who has granted bioRxiv a license to display the preprint in perpetuity. It is made available under ACC-BY-NC-ND 4.0 International license.

Pan-pediatric cancer IncRNA study

Modi et al.

1019 cancer, ranked by highest tau score. Samples from each cancer cluster together based on expression of 1020 these genes alone.

Fig 3: A similar proportion of IncRNAs and protein coding genes are dysregulated due to SCNA

1024 a. The proportion of protein coding and IncRNA genes that have significant differential expression due 1025 SCNA, separated by copy number type (amplification or deletion). The number of genes found in SCNA 1026 loci is shown per cancer. Genes were evaluated to have differential expression due to copy number using 1027 the Wilcoxon rank sum test ( $p$-value < 0.05) and log |fold change| $>1.5)$, comparing samples with no 1028 SCNA to samples with low/high SCNA as defined by GISTIC scores. b. The number of differentially 1029 expressed IncRNAs per chromosome and per cancer, distinguished by color. Chromosome 1 and 17 had 1030 the most dysregulated IncRNAs associating with the greater frequency of SCNA on these chromosomes 1031 across cancers. c. Number of samples with structural variant breakpoints in or near (+/- 2.5kb) IncRNAs 1032 and that are also located in copy number regions, stratified by amplification or deletion status of the locus.

\section{Fig 4: IncRNA modulators impact transcriptional networks involving proliferation.}

1036 a. Schematic that shows the three ways (attenuate, enhance, or invert) in which differentially expressed 1037 IncRNA modulators can impact transcription factor and target gene relationships. IncRNA modulators are 1038 associated with a TF-target gene pair based on a significant difference between TF-target gene 1039 expression correlation in samples with low IncRNA expression (lowest quartile) vs samples with high 1040 IncRNA expression (highest quartile). b. The proportion of IncRNA modulator types associated with 1041 significantly dysregulated IncRNA modulator- TF-target gene (IncMod) triplets. The number of 1042 significantly dysregulated IncMod triplets is listed per cancer. c. Number of IncRNA modulators genes 1043 that are common in IncMod triplets across cancers. Common IncRNA modulator genes tend to have a 1044 lower tau score compared to IncRNA modulators only associated with one cancer. d. Gene set 
bioRxiv preprint doi: https://doi.org/10.1101/2020.12.10.420257; this version posted April 7, 2021. The copyright holder for this preprint (which

was not certified by peer review) is the author/funder, who has granted bioRxiv a license to display the preprint in perpetuity. It is made available under aCC-BY-NC-ND 4.0 International license.

Pan-pediatric cancer IncRNA study

Modi et al.

1045 enrichment using the MSigDB Hallmark gene set, of target genes associated with IncRNA modulators in 1046 each cancer (Fisher's exact test, FDR < 0.1). e. Transcription factors associated with the B-ALL 1047 expression specific IncRNA, BLACE, ranked based on number of regulated target genes. f. Expression 1048 heatmap of BLACE and the target genes of the XBP1 transcription factor, grouped by associated hallmark 1049 gene set, in samples within the bottom and top quartiles of BLACE expression in B-ALL.

1052 Fig 5: Identification of IncRNAs associated with distinct neuroblastoma cell states

1053 a. The MES and ADRN signature score for TARGET NBL samples, with each sample labeled with either 1054 ADRN, Mixed, or MES phenotype based on clustering analysis. b. Heatmap of the expression of IncRNAs 1055 that have significant correlation with either the MES or ADRN score $(|r|>0.6$, pval $<0.01)$. IncRNAs were correlated with protein coding genes on the same chromosome and subsequent gene set enrichment analysis was performed for MES and ADRN protein coding genes separately. c. Schematic of how ADRN associated CRC regulated genes are identified using ChIP-seq and chromatin interaction data. We identified IncRNAs based on three types of regulation. 1) CRC transcription factors binding directly at the promoter of the IncRNA. 2) CRC TFs bind an enhancer region that interacts with a IncRNA promoter. 3)

1061 CRC TFs bind the promoter of a different gene and this promoter interacts with a IncRNA promoter. CRC 1062 TF binding was identified from ChIP-seq data, while enhancer-promoter and promoter-promoter 1063 interactions were identified from chromatin capture data. d. Filtering of IncRNAs expressed in NBL based 1064 on CRC TF regulation and differential expression based on sample phenotypes (ADRN or MES). e. 1065 Expression of TBX2 and TBX2-AS1 stratified by NBL sample phenotype (ADRN or MES). f. ChIP-seq 1066 tracks for histone marks and CRC transcription factors in the NBL cell line: $\mathrm{BE}(2) \mathrm{C}$, and promoter capture 1067 C chromatin interactions in NBL cell line: NB1643, at the TBX2/TBX2-AS1 locus. 
bioRxiv preprint doi: https://doi.org/10.1101/2020.12.10.420257; this version posted April 7, 2021. The copyright holder for this preprint (which was not certified by peer review) is the author/funder, who has granted bioRxiv a license to display the preprint in perpetuity. It is made

Pan-pediatric cancer IncRNA study

Modi et al.

1071 a. Expression of TBX2 and TBX2-AS1 in NBL tumor samples with and without $17 q$ gain. b. The top 1072 MSigDB Hallmarks enriched across targets genes ( $p$-value < 0.01) regulated by TBX2-AS1 as predicted 1073 from IncMod analysis. c. The transcription factors with most target genes regulated by TBX2-AS1 as 1074 predicted from IncMod analysis. d. Expression of gene targets of the E2F1 transcription factor that are 1075 enriched for proliferation hallmarks, in samples with low and high TBX2 and TBX2-AS1 expression. TBX2 1076 expression is highly correlated with that of TBX2-AS1 (Pearson's $r=0.77$ ). e. siRNA knockdown efficiency 1077 of TBX2-AS1 in the NBL cell line: NLF is $91 \%$ and in the SKNSH cell $63 \%$ knockdown was achieved. $\mathbf{f}$. 1078 Western blot analysis of TBX2 in siTBX2 and siTBX2-AS1 treated NLF and SKNSH cell lines. $\mathbf{g}$. 1079 Representative image of cell growth (as measured by RT-Ces assay) of the NBL cell lines: NLF and $\mathbf{h}$. $1080 \mathrm{SKNSH}$. Cell index is normalized to time point when siRNA reagent is added at 24 hours post cell plating. 1081 i. Results from iRegulon analysis for genes that are up- or down-regulated upon siTBX2-AS1 treatment 1082 in NLF. Number of genes shown in Venn diagram with evidence of motif or ChIP-seq binding of the listed 1083 transcription factors. 
bioRxiv preprint doi: https://doi.org/10.1101/2020.12.10.420257; this version posted April 7, 2021. The copyright holder for this preprint (which was not certified by peer review) is the author/funder, who has granted bioRxiv a license to display the preprint in perpetuity. It is made

\section{Figure 1}

a

\begin{tabular}{|c|c|}
\hline \multicolumn{2}{|c|}{$\begin{array}{l}\text { Therapeutically Applicable Research to } \\
\text { Generate Effective Treatments (TARGET }\end{array}$} \\
\hline \multicolumn{2}{|c|}{ RNA-seq $(N=1044)$} \\
\hline $\begin{array}{l}\text { Acute myeloid } \\
\text { leukemia (AML) } \\
\qquad N=280\end{array}$ & $\begin{array}{c}\text { Neuroblastoma } \\
\text { (NBL) } \\
N=161\end{array}$ \\
\hline $\begin{array}{c}\text { B-lineage } \\
\text { acute lymphoblastic } \\
\text { leukemia (B-ALL) } \\
\mathrm{N}=190\end{array}$ & $\begin{array}{c}\text { Wilm's } \\
\text { tumors (WT) } \\
\mathrm{N}=121\end{array}$ \\
\hline $\begin{array}{c}\text { T-lineage } \\
\text { acute lymphoblastic } \\
\text { leukemia (T-ALL) } \\
\mathrm{N}=244\end{array}$ & $\begin{array}{c}\text { Rhabdoid } \\
\text { tumors (RT) } \\
\mathrm{N}=48\end{array}$ \\
\hline
\end{tabular}

b

pediatric cancer transcriptome

novel IncRNA: 145

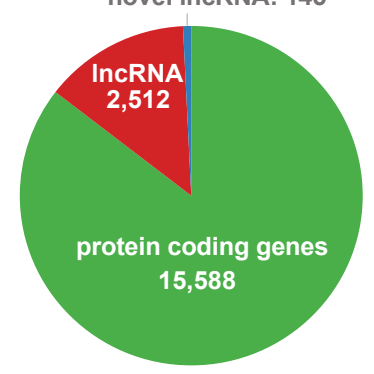

C

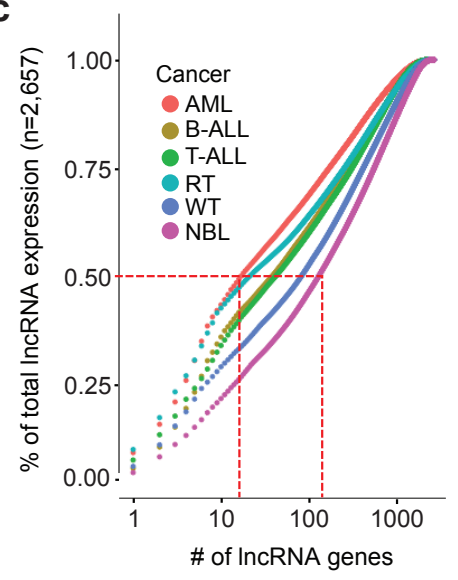

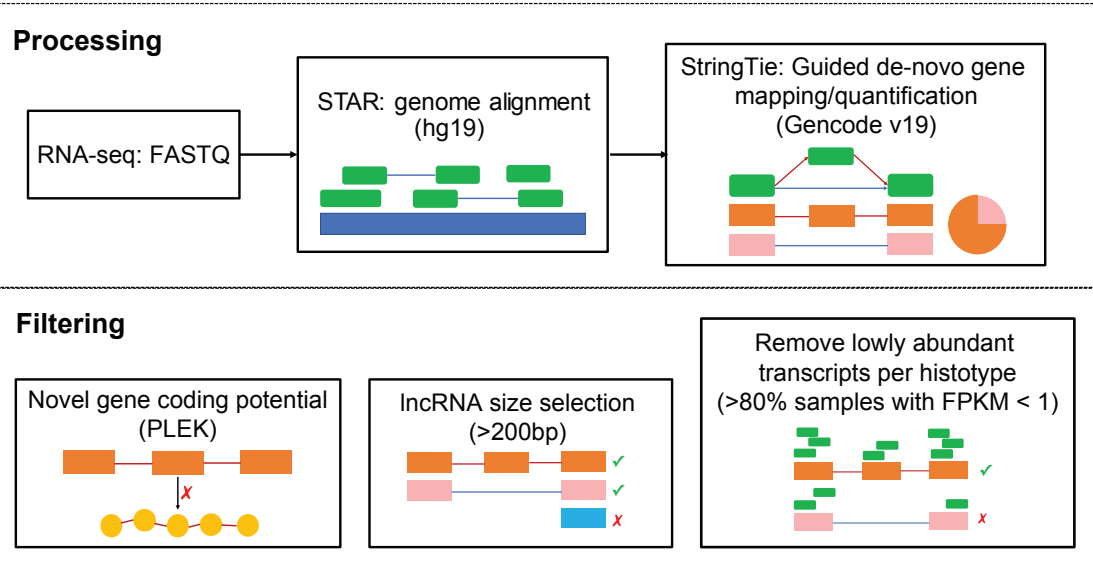
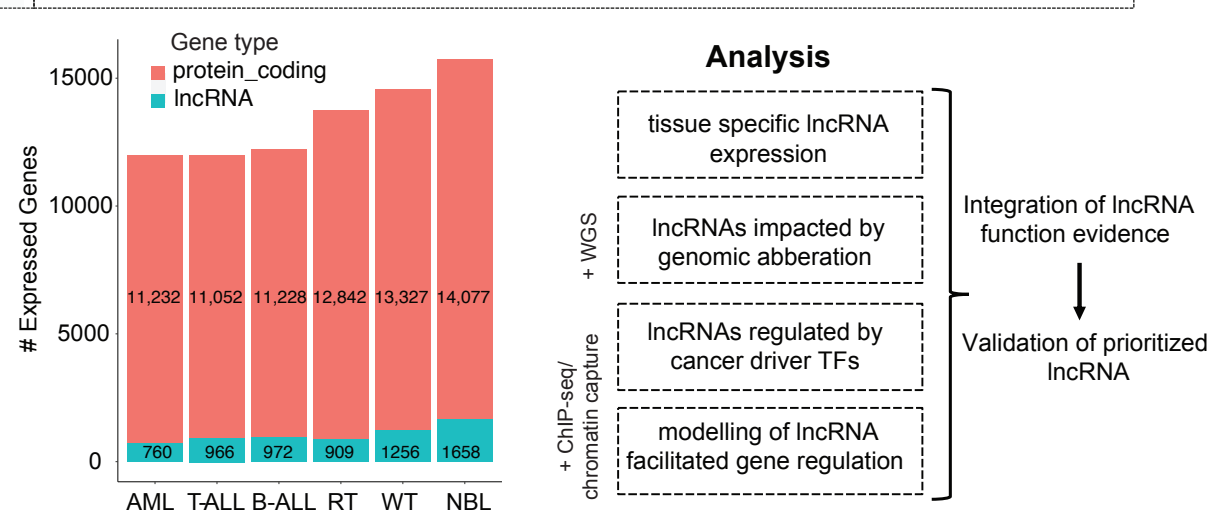

d

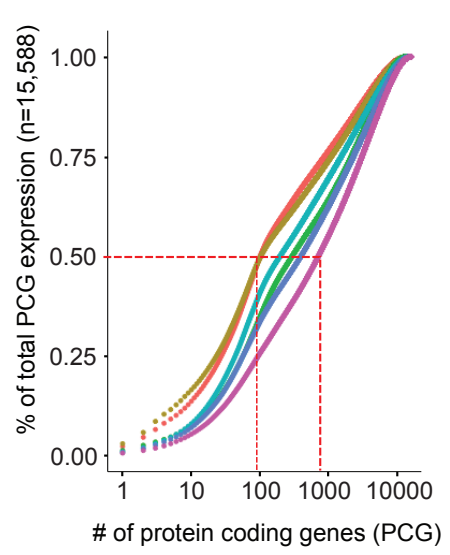

e

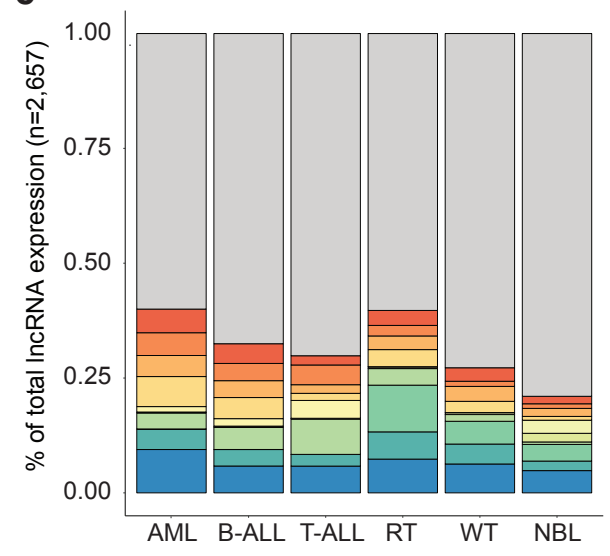

$\square Z F A S 1$ 口SNHG8 口 SNHG6 $\square$ SNHG5 口RP11-386/14.4 口RP11-386G11.10 口 MEG3 $\square$ MALAT1 $\square \mathrm{H} 19$ $\square$ GAS5 $\square$ C17orf76-AS1 $\square$ all other IncRNAs

Fig 1: Pan-pediatric transcriptome characterization.

a. Overview of pan-pediatric cancer RNA-seq dataset and schematic of data processing and filtering. Reads from RNA-seq fastq files were aligned using the STAR algorithm and then gene transcripts were mapped in a guided de novo manner and quantified via the StringTie algorithm. Genes were considered novel if they did not have transcript exon structures matching genes in the GENCODE v19 or RefSeq v74 databases. Novel genes were assigned as IncRNAs based on length $>200 \mathrm{bp}$ and non-coding potential calculated using the PLEK algorithm. Transcripts with low expression (FPKM $<1$ in $>80 \%$ samples) were not considered for further analysis. b. Pie graph showing the quantity of expressed and robustly expressed protein coding genes, GENCODE/RefSeq annotated IncRNAs, and novel IncRNAs. High confidence expressed genes are distinguished from all expressed genes. Adjoining schematic gives overview of additional data types that were integrated with transcriptome data: WGS, ChIP-seq, and chromatin capture. Listed are the analyses used to elucidate IncRNAs with functional roles in pediatric cancer. c. Cumulative expression plots comparing the number of IncRNAs and (d) protein coding genes, respectively, that constitute the total sum of gene expression (FPKM) per pediatric cancer. e. Percentage of total IncRNA expression (FPKM) accounted for by the union of top five expressed IncRNAs per cancer (total 11 IncRNAs). 


\section{Figure 2}

a

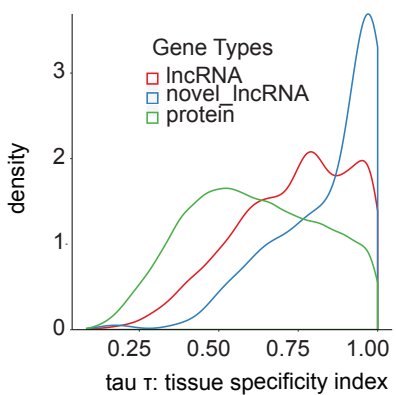

\begin{tabular}{|l|c|c|c|}
\hline Gene Type & Protein & IncRNA & Novel IncRNA \\
\hline Tau score range & $0.084-0.999$ & $0.102-0.999$ & $0.175-0.999$ \\
\hline Tau score mean & 0.610 & 0.735 & 0.849 \\
\hline
\end{tabular}

b

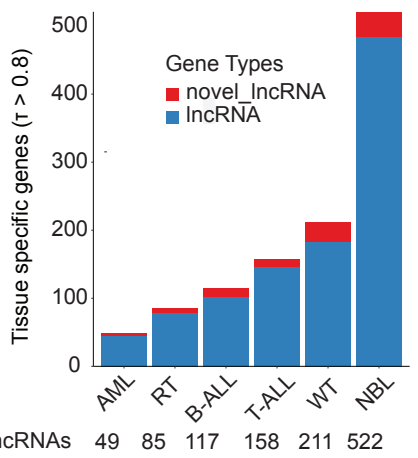

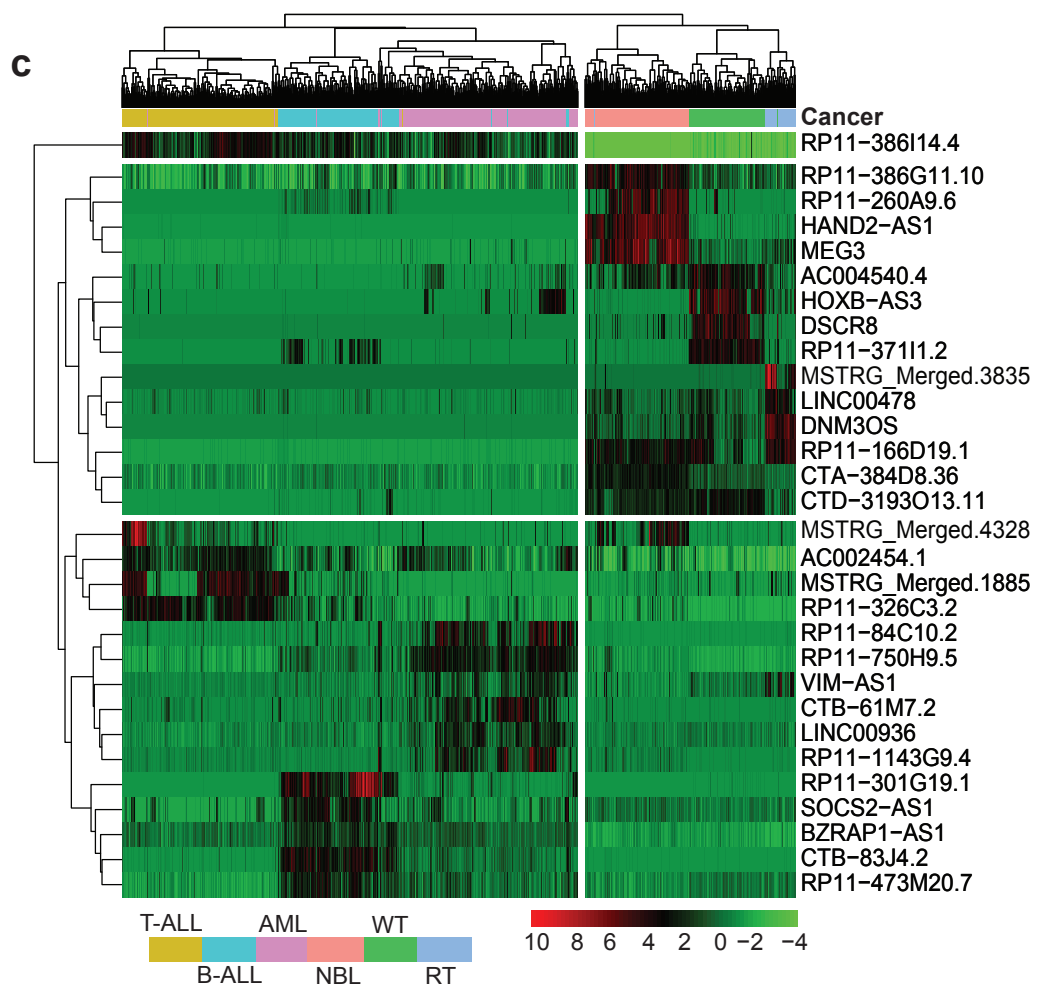

Fig 2: IncRNAs exhibit tissue specific expression that can distinguish cancers.

a. Tissue specificity index (tau score) which ranges from 0 (ubiquitously expressed) to 1 (tissue specific) is plotted for genes across three gene types: protein coding genes, IncRNAs, and novel IncRNAs. Table shows the tau score range and mean per gene type. b. Number of tissue specific known and novel IncRNAs in each cancer as defined by tissue specific gene threshold: tau score $>0.8$. c. Heatmap showing the hierarchically clustered gene expression for the top five most tissue specific IncRNAs per cancer, ranked by highest tau score. Samples from each cancer cluster together based on expression of these genes alone. 


\section{Figure 3}
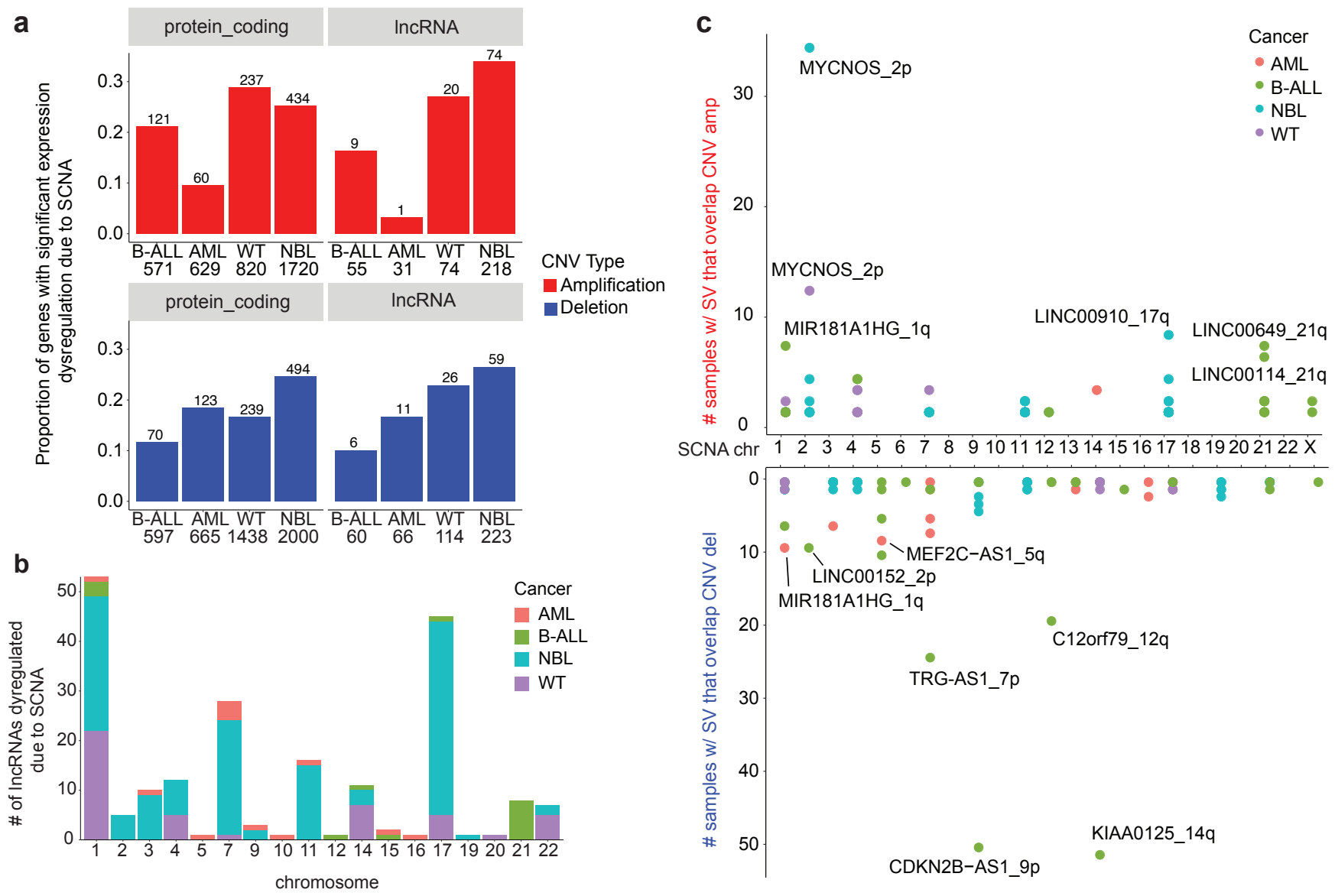

Fig 3: A similar proportion of IncRNAs and protein coding genes are dysregulated due to SCNA

a. The proportion of protein coding and IncRNA genes that have significant differential expression due SCNA, separated by copy number type (amplification or deletion). The number of genes found in SCNA loci is shown per cancer. Genes were evaluated to have differential expression due to copy number using the Wilcoxon rank sum test ( $p$-value $<0.05$ ) and log |fold change| > 1.5), comparing samples with no SCNA to samples with low/high SCNA as defined by GISTIC scores. b. The number of differentially expressed IncRNAs per chromosome and per cancer, distinguished by color. Chromosome 1 and 17 had the most dysregulated IncRNAs associating with the greater frequency of SCNA on these chromosomes across cancers. c. Number of samples with structural variant breakpoints in or near $(+/-2.5 \mathrm{~kb})$ IncRNAs and that are also located in copy number regions, stratified by amplification or deletion status of the locus. 
bioRxiv preprint doi: https://doi.org/10.1101/2020.12.10.420257; this version posted April 7, 2021. The copyright holder for this preprint (which was not certified by peer review) is the author/funder, who has granted bioRxiv a license to display the preprint in perpetuity. It is made

\section{Figure 4} available under aCC-BY-NC-ND 4.0 International license.

a

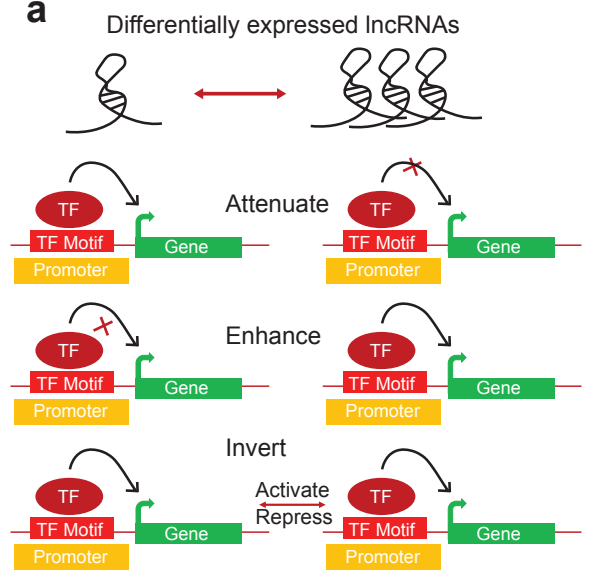

b

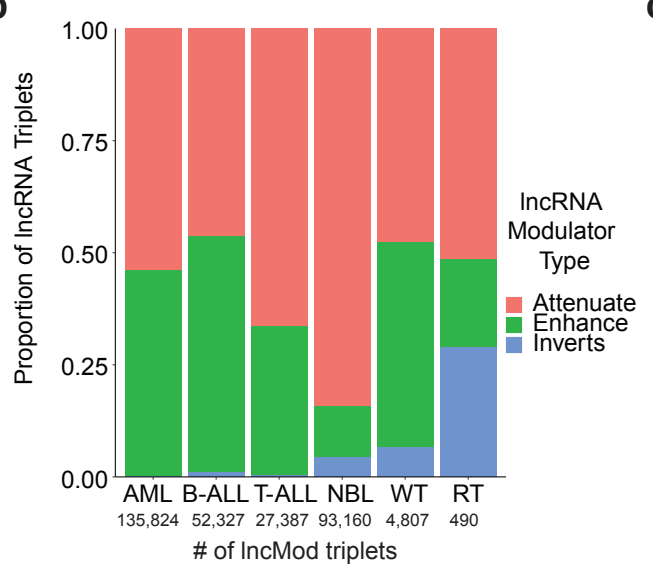

C

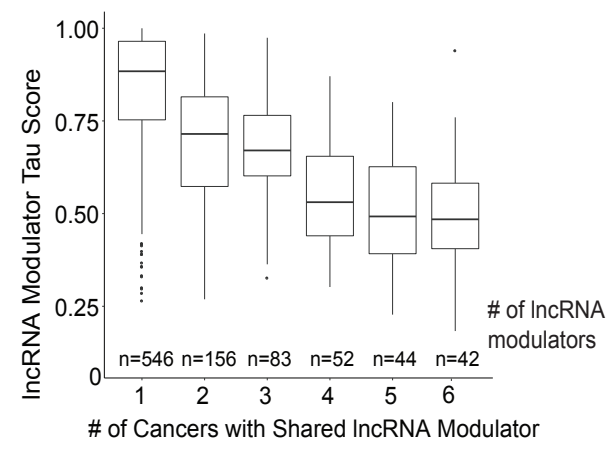

e

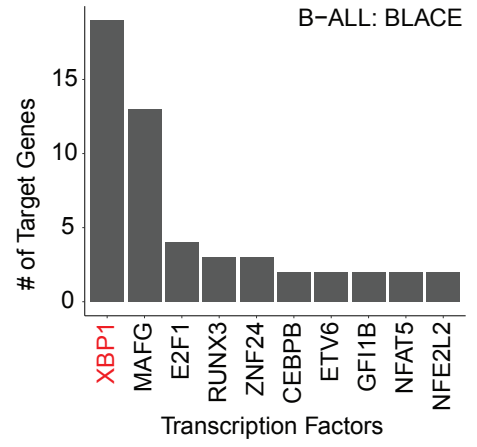

$\mathbf{f}$

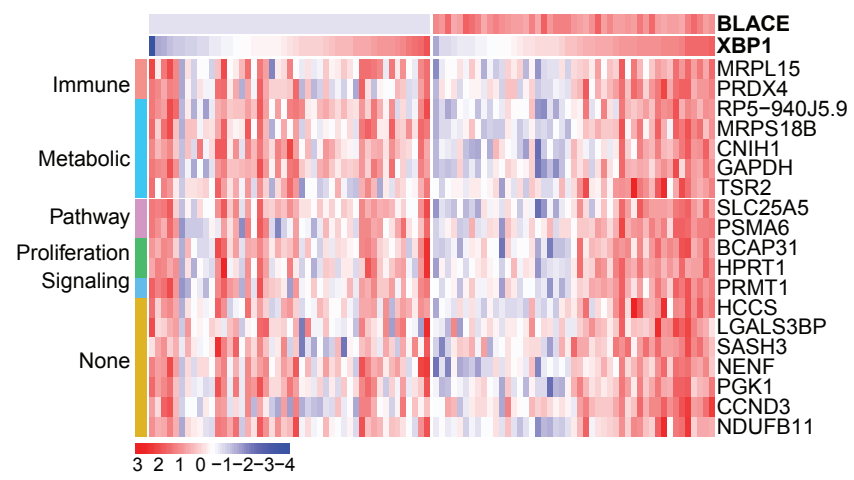

d

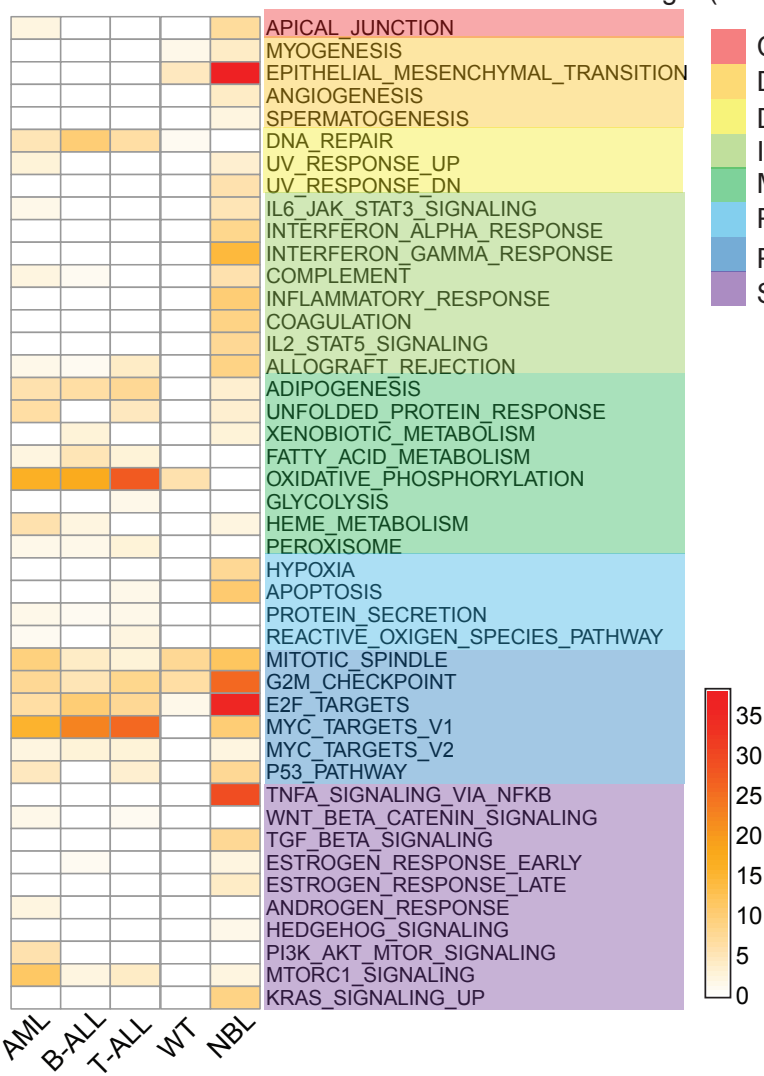

Cellular component Development DNA damage Immune Metabolic Pathway Proliferation Signaling

Fig 4: IncRNA modulators impact transcriptional networks involving proliferation.

a. Schematic that shows the three ways (attenuate, enhance, or invert) in which differentially expressed IncRNA modulators can impact transcription factor and target gene relationships. IncRNA modulators are associated with a TF-target gene pair based on a significant difference between TF-target gene expression correlation in samples with low IncRNA expression (lowest quartile) vs samples with high IncRNA expression (highest quartile). b. The proportion of IncRNA modulator types associated with significantly dysregulated IncRNA modulator- TF-target gene (IncMod) triplets. The number of significantly dysregulated IncMod triplets is listed per cancer. c. Number of IncRNA modulators genes that are common in IncMod triplets across cancers. Common IncRNA modulator genes tend to have a lower tau score compared to IncRNA modulators only associated with one cancer. d. Gene set enrichment using the MSigDB Hallmark gene set, of target genes associated with IncRNA modulators in each cancer (Fisher's exact test, FDR < 0.1). e. Transcription factors associated with the B-ALL expression specific IncRNA, $B L A C E$, ranked based on number of regulated target genes. $\mathbf{f}$. Expression heatmap of $B L A C E$ and the target genes of the XBP1 transcription factor, grouped by associated hallmark gene set, in samples within the bottom and top quartiles of BLACE expression in B-ALL. 
Figure 5

a

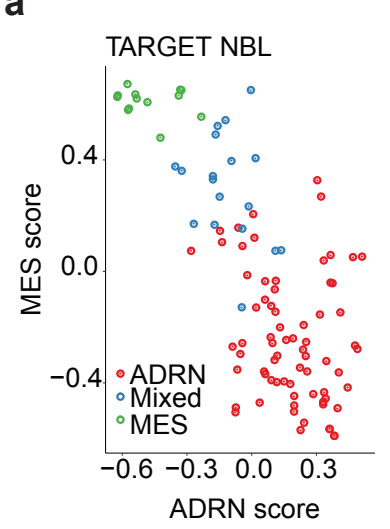

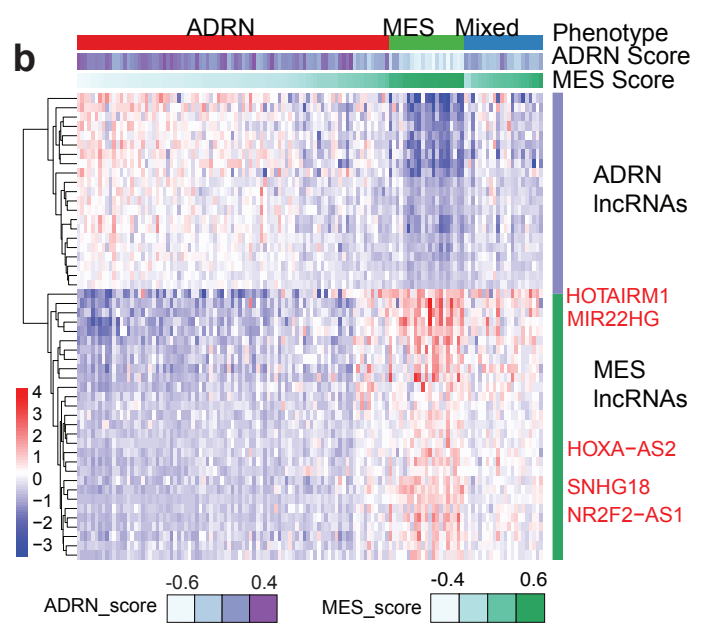

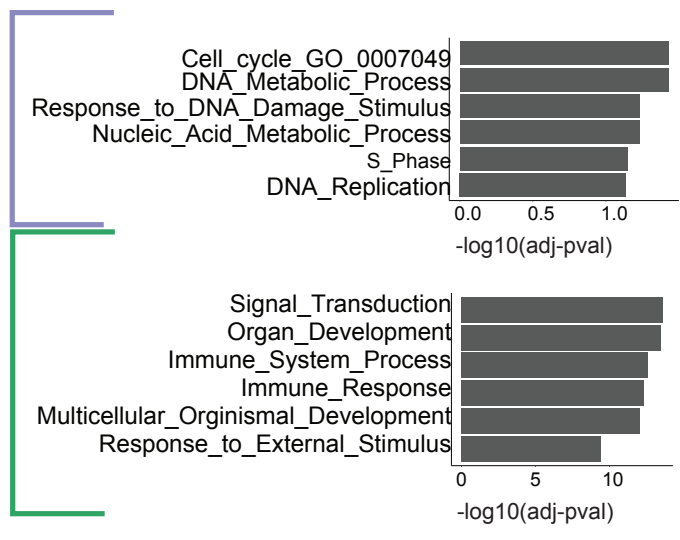

(3) Promoter of gene interacts with CRC TF bound

regulatory regions: enhancers
(1) Promoter of gene $e_{x}$ is bound by CRC TFs
(2) Promoter of gene $e_{x}$ interacts with CRC TF bound promoter of gene

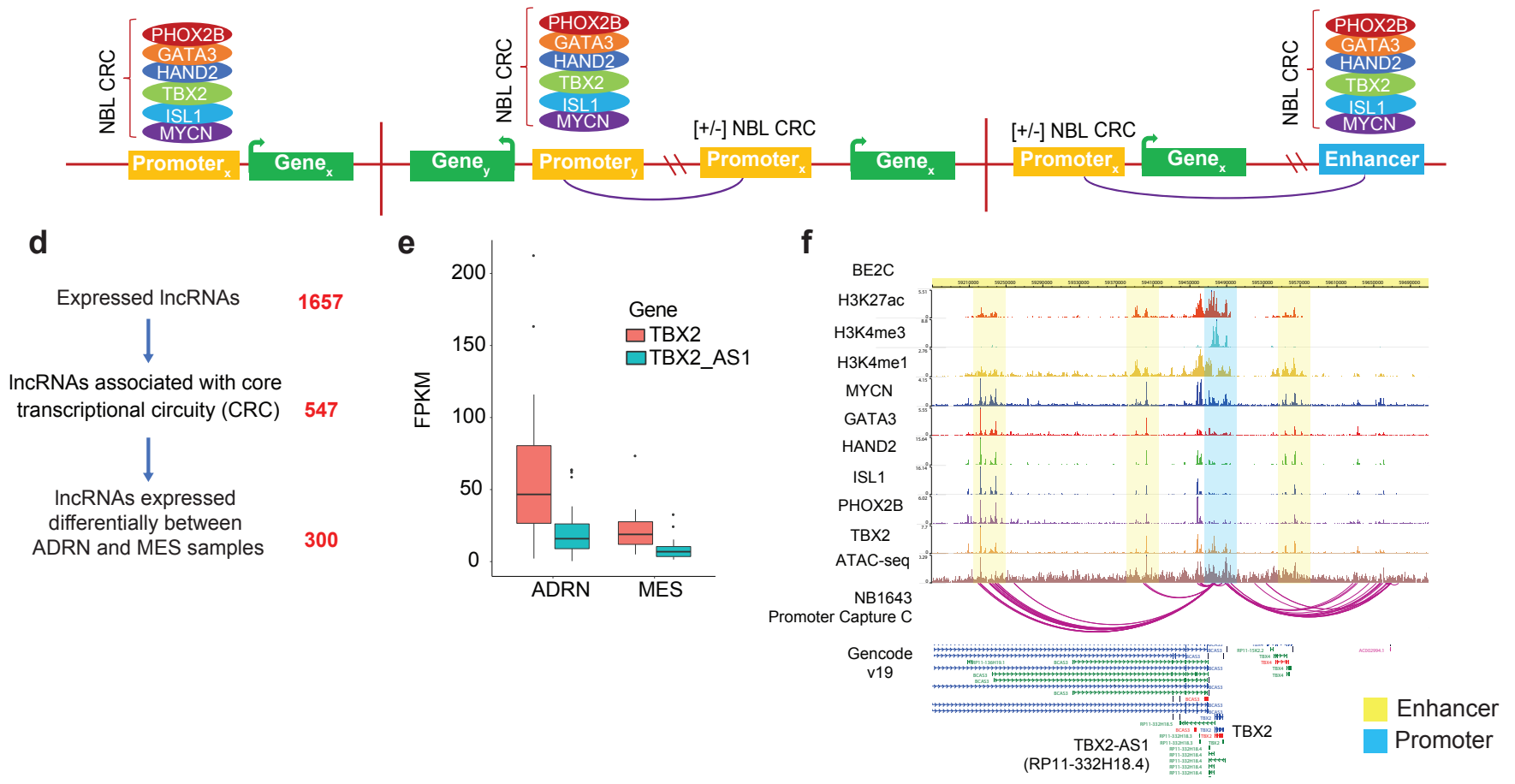

Fig 5: Identification of IncRNAs associated with distinct neuroblastoma cell states

a. The MES and ADRN signature score for TARGET NBL samples, with each sample labeled with either ADRN, Mixed, or MES phenotype based on clustering analysis. b. Heatmap of the expression of IncRNAs that have significant correlation with either the MES or ADRN score (|r| $>0.6$, pval < 0.01). IncRNAs were correlated with protein coding genes on the same chromosome and subsequent gene set enrichment analysis was performed for MES and ADRN protein coding genes separately. c. Schematic of how ADRN associated CRC regulated genes are identified using ChIP-seq and chromatin interaction data. We identified IncRNAs based on three types of regulation. 1) CRC transcription factors binding directly at the promoter of the IncRNA. 2) CRC TFs bind an enhancer region that interacts with a IncRNA promoter. 3) CRC TFs bind the promoter of a different gene and this promoter interacts with a IncRNA promoter. CRC TF binding was identified from ChIP-seq data, while enhancer-promoter and promoter-promoter interactions were identified from chromatin capture data. d. Filtering of IncRNAs expressed in NBL based on CRC TF regulation and differential expression based on sample phenotypes (ADRN or MES). e. Expression of TBX2 and TBX2-AS1 stratified by NBL sample phenotype (ADRN or MES). f. ChIPseq tracks for histone marks and CRC transcription factors in the NBL cell line: $B E(2) C$, and promoter capture $\mathrm{C}$ chromatin interactions in NBL cell line: NB1643, at the TBX2/TBX2-AS1 locus. 


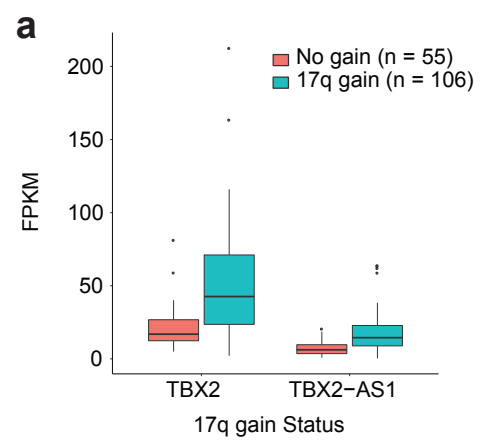

d

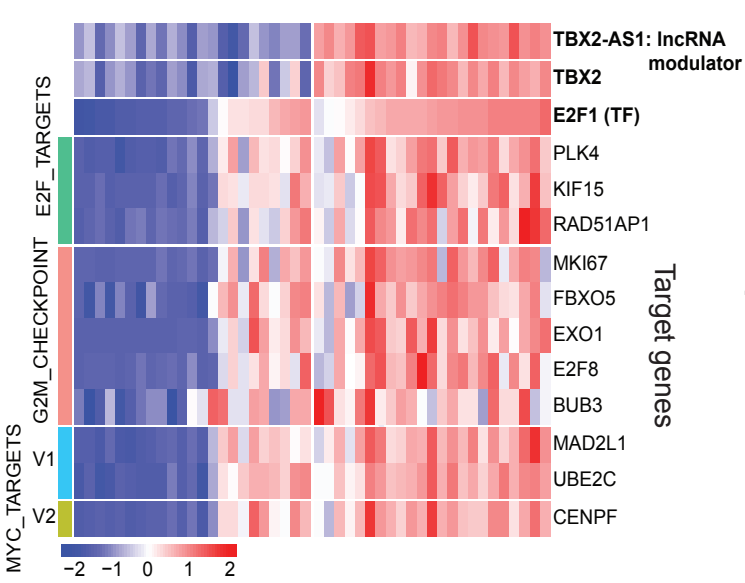

b

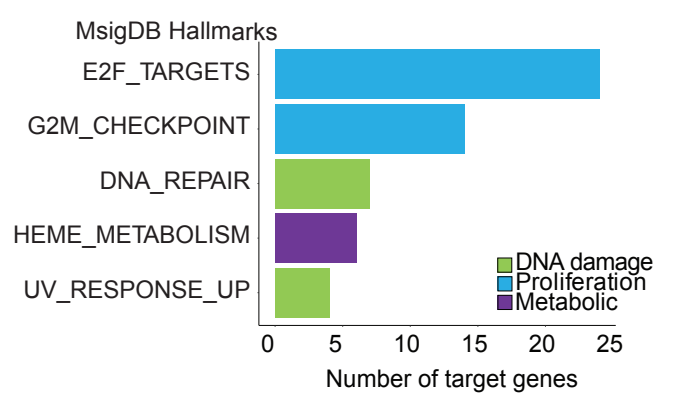

e

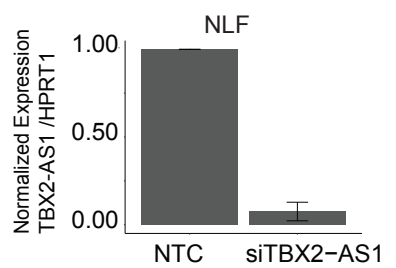

f

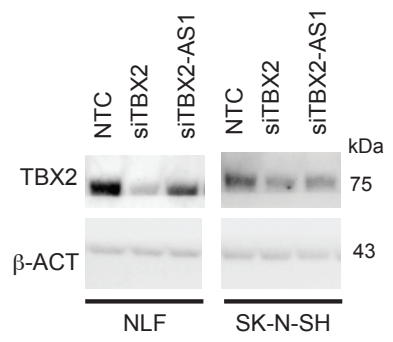

C
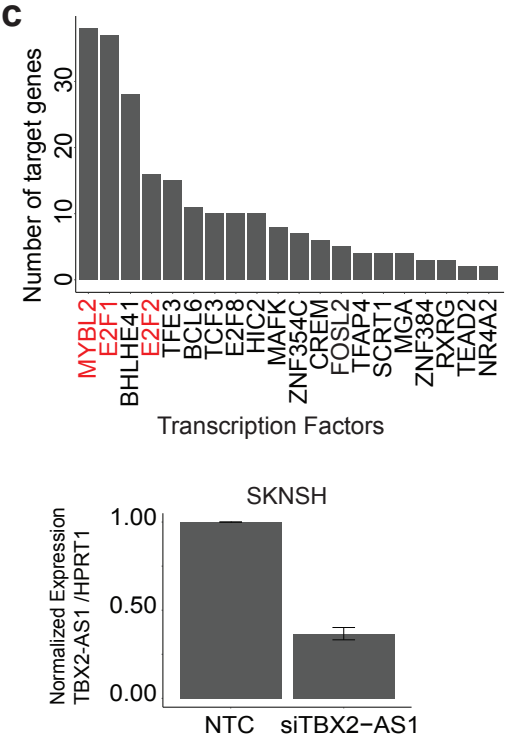
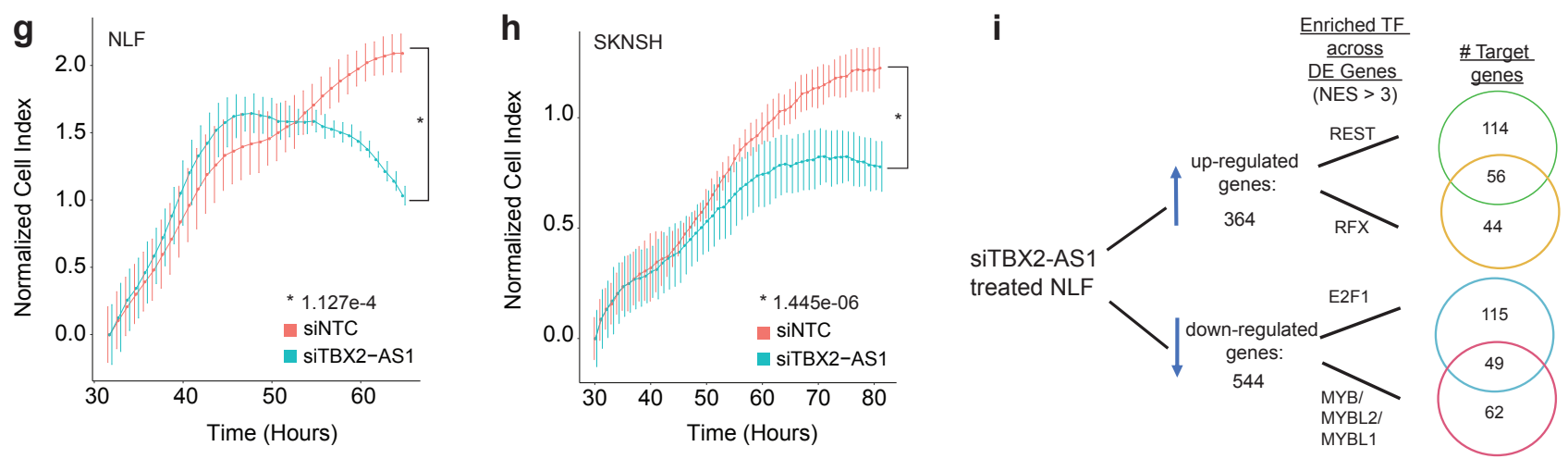

Fig 6: The TBX2-AS1 IncRNA plays a role in neuroblastoma proliferation by modulating TBX2

a. Expression of TBX2 and TBX2-AS1 in NBL tumor samples with and without $17 q$ gain. b. The top MSigDB Hallmarks enriched across targets genes ( $p$-value $<0.01$ ) regulated by TBX2-AS1 as predicted from IncMod analysis. c. The transcription factors with most target genes regulated by TBX2-AS1 as predicted from IncMod analysis. d. Expression of gene targets of the E2F1 transcription factor that are enriched for proliferation hallmarks, in samples with low and high $T B X 2$ and TBX2-AS1 expression. TBX2 expression is highly correlated with that of TBX2-AS1 (Pearson's $r=0.77$ ). e. siRNA knockdown efficiency of TBX2-AS1 in the NBL cell line: NLF is $91 \%$ and in the SKNSH cell $63 \%$ knockdown was achieved. f. Western blot analysis of TBX2 in siTBX2 and siTBX2-AS1 treated NLF and SKNSH cell lines. g. Representative image of cell growth (as measured by RT-Ces assay) of the NBL cell lines: NLF and $\mathbf{h}$. SKNSH. Cell index is normalized to time point when siRNA reagent is added at 24 hours post cell plating. i. Results from iRegulon analysis for genes that are up- or down-regulated upon siTBX2-AS1 treatment in NLF. Number of genes shown in Venn diagram with evidence of motif or ChIP-seq binding of the listed transcription factors. 